Article

\title{
Towards a Tidal Farm in Banks Strait, Tasmania: Influence of Tidal Array on Hydrodynamics
}

\author{
Christelle Auguste ${ }^{1, *(\mathbb{D}}$, Philip Marsh ${ }^{1}$, Jean-Roch Nader ${ }^{1}$, Remo Cossu ${ }^{2}$ and Irene Penesis ${ }^{1}$ \\ 1 Australian Maritime College, University of Tasmania, Launceston, TAS 7250, Australia; \\ philip.marsh@utas.edu.au (P.M.); jeanroch.nader@utas.edu.au (J.-R.N.); i.penesis@utas.edu.au (I.P.) \\ 2 School of Civil Engineering, University of Queensland, St Lucia, QLD 4072, Australia; r.cossu@uq.edu.au \\ * Correspondence: christelle.auguste@utas.edu.au
}

Received: 14 September 2020; Accepted: 1 October 2020; Published: 13 October 2020

\begin{abstract}
The development of tidal energy in Australia is still a challenge with few studies performed on the characterisation of the resource, due to the difficulty to acquire data and uncertainties about the influence of this anthropogenic activity on the marine environment. Changes in flow could lead to alterations in sediment transport and have further influence on the marine habitat. A case study in a promising area, Banks Strait (Australia), was created using high resolution 2D and 3D models validated against in situ data to investigate changes to hydrodynamic conditions with two scenarios of tidal farms (100 and 300 turbines). Comparison between 2D and 3D is performed to find the best compromise between model accuracy and computational time for preliminary assessment. Changes to current speed and bed shear stress over a 35 day period were found to be localised around the tidal farms and did not extent more than $7 \mathrm{~km}$ from the farm (300 turbines) for both 2D and 3D. The results showed that for near field and far field, 2D models are sufficient to give a first approximation of the hydrodynamic influence of tidal farm deployment on its environment.
\end{abstract}

Keywords: tidal energy; hydrodynamic model; tidal farm; environmental impact assessment

\section{Introduction}

The development of tidal industry has made significant progress over the last decades: numerous tidal projects are under way, examples include development in United Kingdom (Pentland Firth, Shetland, Orkney), in France (Ushant, Aldernay Race) and in China (Zhoustan Archipelago) [1]. There also have been considerable advances in numerical models in the recent years, to assess the influence of tidal farms on the environment principally in 2D [2-12]. However, the conclusions of all these studies are site-specific and dependent on device design; thus, the effects of array size will need to be investigated in the site of interest. Generally, 2D models are used for regional modelling while 3D models are used to assess the local tidal energy resource. Nowadays researchers tend to use 3D models to assess the resource and the environmental impact, although at higher computational costs [13].

The objectives for 2030 for Australia (reducing $\mathrm{CO}_{2}$ emissions to 26-28\% below 2005 levels) and Tasmania's plan to become $200 \%$ in renewables by 2040 are a major challenge. To meet these obligations, the Australian government is considering to speed up the deployment of ocean energy, looking towards blue economy projects to reduce fossil fuels reliance. Fourteen Australian tidal power trials have taken place over the last two decades, they are summarised in Table 1 [1,14]. To assess accurately tidal energy sites, the hydrodynamic conditions that produce effective tidal streams must be determined. Further high resolution projects are required to perform a detailed site assessments in order to evaluate the viable production, environmental influence of Australia's tidal resource and tidal farm development. 
Table 1. Tidal energy trials in Australia adapted from [1,14].

\begin{tabular}{|c|c|c|c|c|c|}
\hline Location & Year & Device Type & Company & Power Rating & $\begin{array}{l}\text { Indicative Depth } \\
\text { of Operation (m) }\end{array}$ \\
\hline Darwin & 1996 & $\begin{array}{l}\text { Tyson Turbine fluted cone } \\
\text { axial turbine (pontoon) }\end{array}$ & $\begin{array}{c}\text { Northern Territory University } \\
\text { (NTU) }\end{array}$ & $<1 \mathrm{~kW}$ & 1 \\
\hline Darwin & 1998 & $\begin{array}{l}\text { NTU Swenson axial turbine } \\
\text { (pontoon) }\end{array}$ & NTU & $2.2 \mathrm{~kW}$ & $1-2$ \\
\hline King Sound & $\begin{array}{c}2000- \\
2014\end{array}$ & $\begin{array}{l}\text { Barrage dam } \\
\text { investigation }\end{array}$ & $\begin{array}{l}\text { Tidal Energy Australia } \\
\text { and Hydro Tasmania }\end{array}$ & $40 \mathrm{MW}$ & $\backslash$ \\
\hline Clarence river & 2004 & $\begin{array}{l}\text { Aquanator reaction plates } \\
\text { in closed loop track }\end{array}$ & Atlantis Energy Ltd & $5 \mathrm{~kW}$ & 2 \\
\hline San Remo & 2006 & Aquanator & Atlantis Resources & $100 \mathrm{~kW}$ & 2 \\
\hline San Remo & 2007 & $\begin{array}{l}\text { Submersible tidal } \\
\text { generator }\end{array}$ & $\begin{array}{l}\text { HydroGen Power } \\
\text { Industries }\end{array}$ & $5-50 \mathrm{~kW}$ & up to 20 \\
\hline Brisbane & 2007 & $\begin{array}{l}\text { Submersible tidal } \\
\text { generator }\end{array}$ & $\begin{array}{l}\text { HydroGen Power } \\
\text { Industries }\end{array}$ & $5-50 \mathrm{~kW}$ & up to 20 \\
\hline $\begin{array}{l}\text { San Remo/ } \\
\text { Stony Point }\end{array}$ & 2008 & $\begin{array}{l}\text { Floating tidal } \\
\text { turbine laboratory }\end{array}$ & EnGen Institute & $\backslash$ & 2 \\
\hline Corio Bay & 2008 & $\begin{array}{l}\text { Solon ducted } \\
\text { axial turbine }\end{array}$ & Atlantis Resources & $160 \mathrm{~kW}$ & 10 \\
\hline Melbourne & 2009 & $\begin{array}{l}\text { 3D printed multi-axis } \\
\text { turbine array }\end{array}$ & Cetus & $1 \mathrm{~kW}$ & 1 \\
\hline Newcastle & 2012 & $\begin{array}{l}\text { Sea Urchin } \\
\text { axial turbine (pontoon) }\end{array}$ & Elementary Energy Tech. & $2 \mathrm{~kW}$ & $1-2$ \\
\hline San Remo & 2012 & $\begin{array}{l}\text { Cross-flow turbine } \\
\text { tidal desalination }\end{array}$ & Infra Tidal & $15 \mathrm{~kW}$ & 2.5 \\
\hline Tamar Estuary & 2016 & $\begin{array}{l}\text { Ducted axial turbine } \\
\quad \text { (pontoon) }\end{array}$ & Mako & $10 \mathrm{~kW}$ & 2 \\
\hline Gladstone port & 2018 & Ducted axial turbine & Mako & $\backslash$ & $\backslash$ \\
\hline
\end{tabular}

The Australian Tidal Energy (AUSTEn) project [15] funded by the Australia Renewable Energy Agency (ARENA) aims to map Australian tidal energy resource with three components. One includes the characterization of two promising sites (the Banks Strait in Tasmania and the Clarence Strait in Northern Australia) with a focus on the energy resource potential, the influence on physical parameters and the development of fine-scale models. Banks Strait (Figure 1), a strait located in the north east of Tasmania between Swan Island and Clarke Island, has been identified as suitable for commercial tidal farm developments [16]. This $15 \mathrm{~km}$ wide strait connects the Tasman Sea to the south east of Bass strait: which due to its strong currents and proximity to grid-connection is a very attractive site for the development of the tidal arrays in Australia. Preliminary coarse resolution hydrodynamic modelling by the Commonwealth Scientific and Industrial Research Organisation (CSIRO) indicated strong currents of around $2.5 \mathrm{~m} / \mathrm{s}$ in this area [17] and more recently [18] found an area of $9 \mathrm{~km}^{2}$ south of Clarke Island with maximum current speed higher than $2 \mathrm{~m} / \mathrm{s}$. The surveys performed by the AUSTEn project in Banks Strait in 2018 revealed important coastal features including the presence of large sand dunes near Clarke Island (Figure 1). The deployment of a tidal farm in this area may influence these natural phenomenons.

To assess a tidal energy site, the different steps are the collection of data with surveys, then the numerical modelling of the site to perform Environmental Impact Assessment (EIA). Previously in the Banks Strait region, field measurements such as bathymetry, current velocities, sub-bottom properties and suspended sediment concentration were sparse due to the energetic environment found in this area. Recently the AUSTEn campaigns filled this gap using a large set of instruments and surveys techniques. Most of studies conducted in this region [19-26] have focussed on the current flow through the Bass strait, without focussing specifically on Banks Strait region. This strait was not modelled with a resolution high enough to be reliable for accurate tidal energy site study until recently with new work found in the Banks Strait area: [18] used a $400 \mathrm{~m}$ mesh resolution model which was validated against an Acoustic Wave and Current Profiler (AWAC) field data with no implementation of turbines. More fine-scale modelling is therefore needed in Banks Strait in order to reduce the uncertainty of the influence of tidal energy extraction on the physical environment. To reduce uncertainty in sediment transport rates, hydrodynamic models should be calibrated to less than $10 \%$ errors in the velocity $[27,28]$. Recent literature and the comprehensive review of the current understanding of the hydro-environmental impacts [29] revealed the next challenges for tidal energy: more complex 
physics (3D), models coupling wave and current, very far field effect and one of the most important: field measurements, critical to validate model simulations.

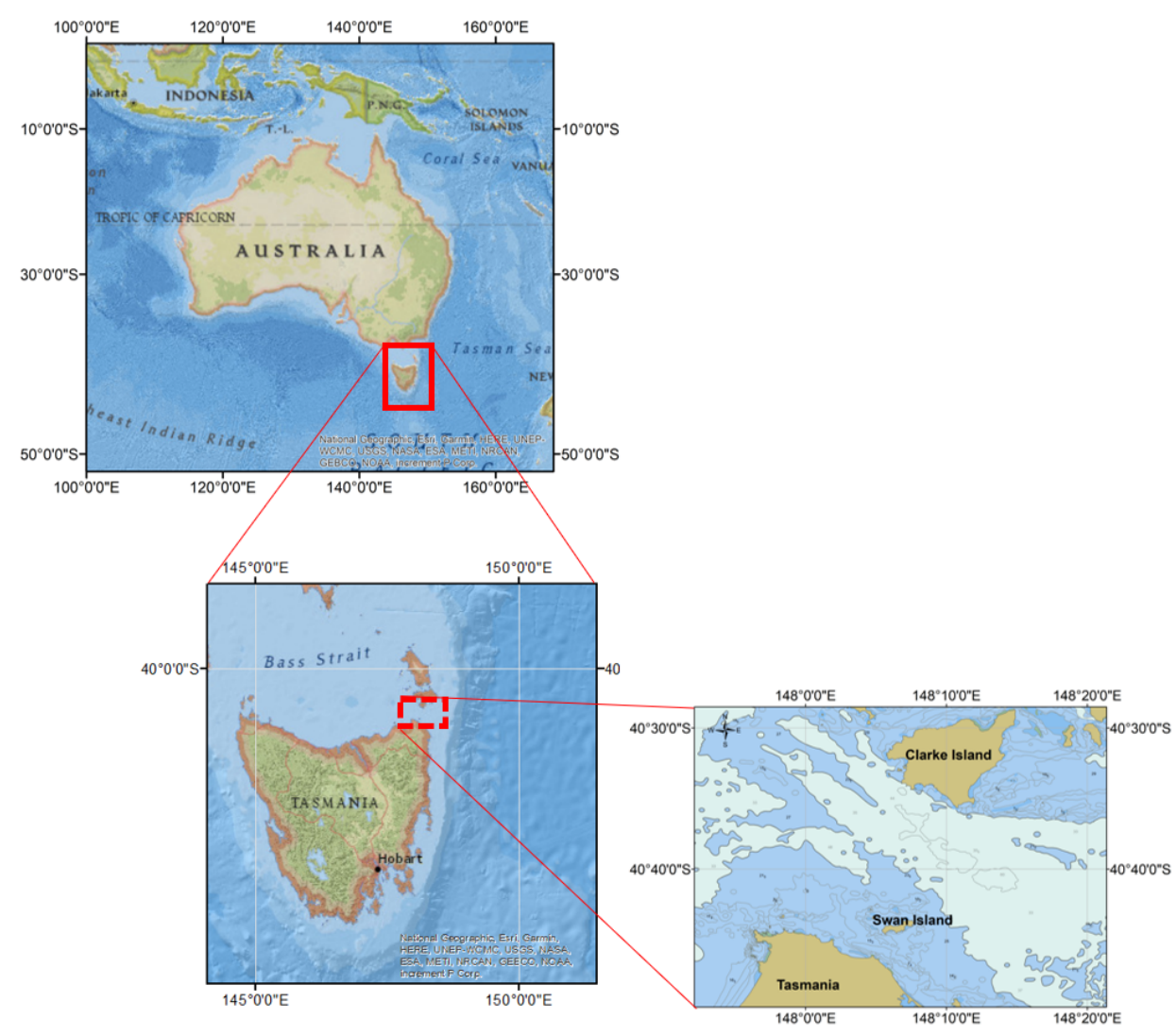

Figure 1. (top) Map of Australia with the location of Tasmania, and (bottom) map of Tasmania showing the location of the Banks Strait with (right) a zoom on the strait.

The aim of this work was to investigate the influence of two tidal farms on physical parameters in Banks Strait using high-resolution 2D and 3D hydrodynamic ocean models. Highly calibrated unstructured mesh hydrodynamic models were validated against a large set of in situ data with implementation of two tidal farms (100 and 300 turbines). Investigation on whether 2D or 3D model dimensions are required for EIA in the near and far field are also presented. Details of the Banks Strait site and the AUSTEn surveys are presented in Section 2, with model validation results presented in Section 3 using field data from the AUSTEn campaigns. The influence in oceanographic systems of two simulated tidal farms is then described in Section 4. This study is also a solid basis for future work to determine the influence of tidal farms on sediment dynamics.

\section{Modelling Methodology}

This section outlines the description of the site, field data, numerical model, forcing inputs and validation process.

\subsection{The Site and Data Collection}

Banks Strait is located in the eastern part of Bass Strait between Clarke Island and the mainland of Tasmania. Principal harmonic constituents in the strait are the semidiurnal M2, S2 and diurnal O1, $\mathrm{K} 1$ with the semidiurnal M2 tide being the principal constituent $[20,25]$. The water mass characteristics of Banks Strait are altered by tidal stirring and local air-sea fluxes: with strong warming in summer and strong cooling in winter [26] and with saltiest water in winter [21]. Currents in the strait are primarily driven by tidal forcing, winds and shelf waves in Bass Strait. In Banks Strait, Sandery [21] 
described the area as well mixed because of the turbulent system due to strong tidal currents occurring. Sandery [20] also mentioned inferred flow in Banks Strait in winter with the sub-Antarctic Surface Water (SASW) intrusion.

The region of Banks Strait has been surveyed in March, July and December 2018, with the AUSTEn project [15], allowing measurements of seasonal variations. Field measurements at up to five stations using Acoustic Doppler Current Profiler (ADCP) were performed in Banks Strait in March, three in July and one in December (Figure 2). The details of ADCP deployments are described in Table 2. These instruments were configured to measure currents, to calibrate and validate the numerical model and were processed using the Integrated Marine Observing System (IMOS) Toolbox [30].

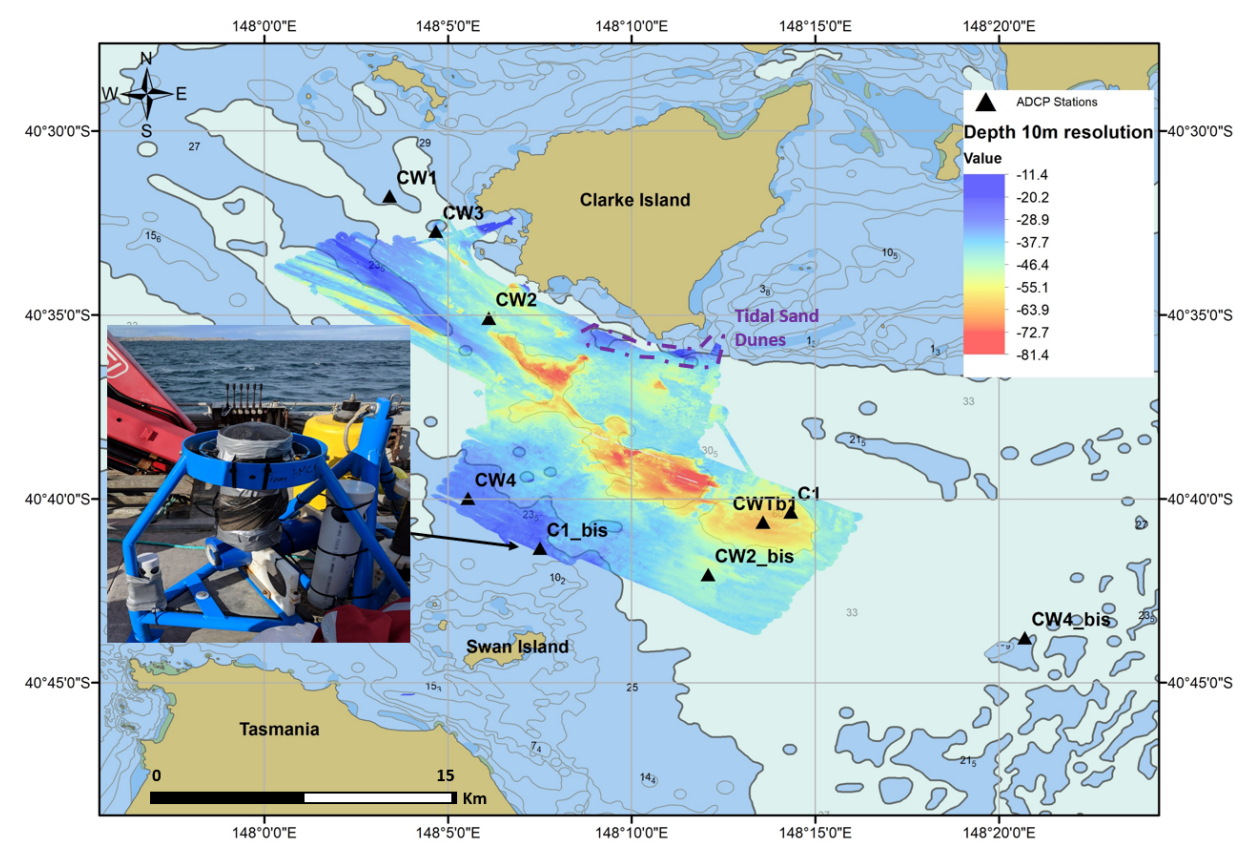

Figure 2. Location of Acoustic Doppler Current Profiler (ADCP) stations and high-resolution bathymetry obtained from the multi-beam survey in Banks Strait with a picture of an ADCP mounted on a frame.

High-resolution bathymetry of the Strait was obtained using the Bathyswath v.1 (ITER system $234 \mathrm{kHz}$ ) between 16/03/2018 and 28/03/2018, with a resolution of approximately $5 \mathrm{~m}$ horizontal and $0.25 \mathrm{~m}$ vertical over an area of approximately $210 \mathrm{~km}^{2}$. The results of this survey showed depths varying between $10 \mathrm{~m}$ and $50 \mathrm{~m}$ with a deeper channel in the middle of Banks Strait with pockets of $70 \mathrm{~m}$ to $100 \mathrm{~m}$. The multi-beam seafloor survey found large sand dunes that vary approximately between 5 and $10 \mathrm{~m}$ south-east of Clarke Island as shown in Figure 2. Field measurements of conductivity Temperature Depth (CTD) casts found vertical fluctuations of less than 5\% [31], confirming the well mixed area in this energetic system and allowing the use of barotropic ocean models without any reduction in simulation accuracy. Data from the AWACS found average wave heights between 1 and $2 \mathrm{~m}$ with maximum values reaching over $5 \mathrm{~m}$ [32]. Studies of the region found currents higher than $2 \mathrm{~m} / \mathrm{s}$ during ebb tides in the middle of the channel with a tidal asymmetry of 20 degrees between ebb and flood at the location of the station CW4 [18]. Maximum power density over $3 \mathrm{~kW} / \mathrm{m}^{2}$ was found in the middle of the channel, exceeding the $2.5 \mathrm{KW} / \mathrm{m}^{2}$ threshold outlined for the economic viability of a site [33]. 
Table 2. Details of ADCP.

\begin{tabular}{|c|c|c|c|c|c|c|c|c|}
\hline Name Station & Type of Instrument & Longitude & Latitude & Depth (m) & Date of Deployment & End of Data Collected & Cell Size (m) & Length (Days) \\
\hline CW2 & RDI Sentinel V50 $500 \mathrm{k} \mathrm{Hz}$ & 148.10188 & -40.5848 & 46.47 & $22 / 03 / 2018$ & $11 / 07 / 2018$ & 0.5 & 110 \\
\hline C1 & RDI Workshorse $300 \mathrm{k} \mathrm{Hz}$ & 148.23882 & -40.6727 & 57.94 & $17 / 03 / 2018$ & $10 / 07 / 2018$ & 2.0 & 115 \\
\hline CW3 & Nortek AWAC 1 M Hz & 148.07778 & -40.5454 & 34.95 & $22 / 03 / 2018$ & $16 / 06 / 2018$ & 0.5 & 86 \\
\hline CW4 & Nortek AWAC $1 \mathrm{M} \mathrm{Hz}$ & 148.09241 & -40.6664 & 30.67 & $15 / 03 / 2018$ & $09 / 06 / 2018$ & 1.0 & 85 \\
\hline CWTb1 & Nortek Signature $500 \mathrm{k} \mathrm{Hz}$ & 148.22626 & -40.6672 & 63.57 & $22 / 03 / 2018$ & $09 / 07 / 2018$ & 1.0 & 109 \\
\hline CW1 & RDI Sentinel V50 500 Hz & 148.05684 & -40.5294 & 27.11 & $12 / 07 / 2018$ & $06 / 09 / 2018$ & 0.5 & 57 \\
\hline CW2 bis & RDI Sentinel V50 $500 \mathrm{~Hz}$ & 148.20132 & -40.701 & 46.08 & $12 / 07 / 2018$ & $22 / 09 / 2018$ & 0.5 & 72 \\
\hline CW4bis & Nortek AWAC $1 \mathrm{M} \mathrm{Hz}$ & 148.34497 & -40.7296 & 25.42 & $13 / 07 / 2018$ & $08 / 09 / 2018$ & 1.0 & 54 \\
\hline C1 bis & RDI Workshorse $300 \mathrm{k} \mathrm{Hz}$ & 148.12498 & -40.6891 & 29.07 & $05 / 12 / 2018$ & $15 / 02 / 2019$ & 1.0 & 72 \\
\hline
\end{tabular}




\subsection{Model Domain and Forcing}

High-resolution numerical models of Banks Strait were developed in 2D and 3D using the unstructured mesh MIKE21 and MIKE3 FM modelling software (DHI A/S, Hørsholm, Denmark). The software solves Reynolds-averaged Navier-Stokes (RANS) equations using the Boussinesq assumption [34]. The numerical domain extends between $38^{\circ} \mathrm{S}$ and $44^{\circ} \mathrm{S}$ and $141^{\circ} \mathrm{E}$ and $150^{\circ} \mathrm{E}$. The mesh resolution varied in the domain from an average of $3 \mathrm{~km}$ at the boundary to $100 \mathrm{~m}$ at the approach of Banks Strait, in the strait the typical node spacing was $50 \mathrm{~m}$ and increased to $20 \mathrm{~m}$ in the area suitable for tidal farm installation and key interest features such as the sand dunes near Clarke Island (Figure 3). The model shoreline data were extracted from the Australian Bathymetry and Topography grid [35] and from Australian Hydrography Service AusEnc charts (AHS) [36] for better resolution in the Banks Strait area (north east coast of Tasmania and Furneaux Islands). Bathymetry data were also collected from Geoscience Australia (GA 2009) [35] for the larger domain, from the AHS for more precise features in the Banks Strait area (between the mainland of Tasmania and Flinders Island) and from the AUSTEn Project (multi-beam in March 2018). The collected bathymetry dataset was interpolated onto an unstructured mesh using the natural neighbour method.

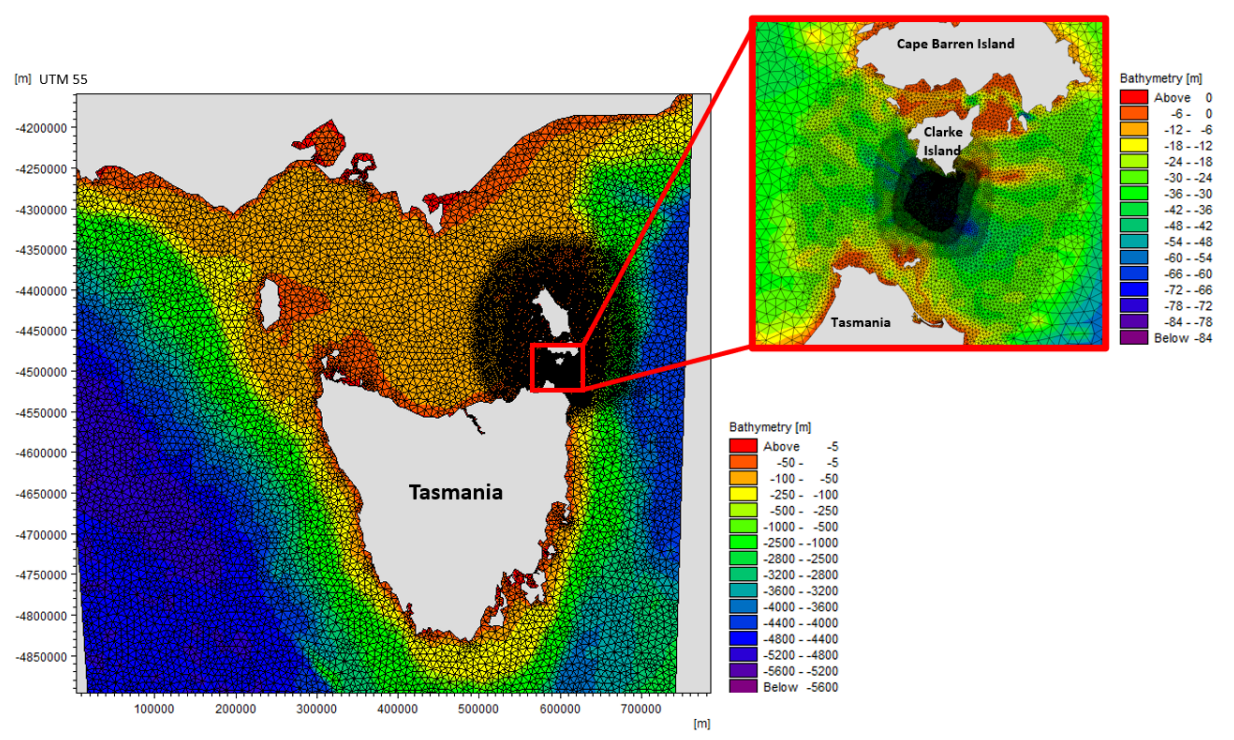

Figure 3. Domain of the numerical domain and a zoom in Banks Strait (Coordinates in UTM 55).

Three open boundaries were forced with tidal constituents (surface elevation) from the Global tide MIKE model [37]. This tide model represents the major diurnal (S1, K1, O1, P1 and Q1), semidiurnal (M2, S2, N2 and K2) and shallow water/nonlinear (M4) constituents with a spatial resolution of $0.125^{\circ} \times 0.125^{\circ}$ based on altimetry data from TOPEX/POSEIDON. The open boundaries were set far beyond Banks Strait to reduce their influence on simulation results as recommended $[7,38]$. The ERA5 climate reanalysis dataset [39] was used for wind components, with the collated dataset mean sea level and pressure closely matching the values from the Bureau of Meteorology measurements [40] in the Banks Strait at Swan Island $\left(R^{2}=0.9\right)$ when compared to the year 2018.

\subsection{Model Settings}

The barotropic models were run for 42 days to follow IEC recommendations [38], with 1 week spin up (to reach a steady state), from 16/03/2018 00:00 to 26/04/2018 00:00, generating a 35-day dataset. The Smagorinsky formulation was used for the horizontal eddy viscosity and the log-law formulation for vertical eddy viscosity. Changes in 3D compared to the 2D setup included the vertical layers and the bed resistance where the roughness height was used and calculated from Manning's number (M). A Manning value of 32 was found to give the best calibration after sensitivity tests in 2D 
with the results shown in Section 3. This Manning value gave us a bottom drag coefficient of 0.0025 which represents a sand/gravel habitat [41]. Vertical dimension was discretised into 19 equidistant vertical layers.

Tidal farms with 100 and 300 turbines were tested to evaluate their influence on hydrodynamics. The tidal turbines were represented as a sub-grid object via an actuator disc model [34], implemented using Matlab scripts to automate the process [42]. The turbines were assumed to be aligned with the flow direction and were modelled using a fixed drag coefficient $C_{D}$ and thus $C_{D}=C_{T}$ (thrust coefficient). The drag force is defined as:

$$
F_{D}=\frac{1}{2} \rho \alpha C_{D} A_{e} U_{0}^{2}
$$

where $\rho$ is the density of water (equal to $1025 \mathrm{~kg} / \mathrm{m}^{3}$ ), $\alpha$ a correction factor (set to 1 in this study), $C_{D}$ is the drag coefficient, $A_{e}$ is the effective area of turbine exposed to current and $U_{0}$ is the upstream current speed. A generic turbine design was used with a diameter of $20 \mathrm{~m}$, with a constant $C_{D}$ setting of 0.85 and the hub height was set to $17 \mathrm{~m} \mathrm{[42]} \mathrm{to} \mathrm{represent} \mathrm{a} \mathrm{first} \mathrm{generation} \mathrm{of} \mathrm{tidal} \mathrm{stream}$ energy converters. Each turbine was arranged in one grid cell of the numerical model for a better representation of the interactions between the turbines. The array layout was arranged with 2.5D (with $\mathrm{D}$ the turbine diameters) lateral spacing, recommended by the European Marine Energy Centre (EMEC) standard [43] and according to [44] inter-device spacing could be less than 3D. For the longitudinal spacing 6D was chosen as a compromise between 10D (recommended by EMEC) who allows better recovery of the flow and the characteristics (bathymetry and area of strong current) of the area.

To enable velocity profile comparisons between the 2D model and the 3D model, the power law defined as:

$$
U_{z}=\left(\frac{z}{\beta h}\right)^{1 / \alpha} \bar{U}
$$

was used to transform the $2 \mathrm{D}$ results. This equation relates the velocity profile $U_{z}$ with bed roughness ( $\beta=0.4$ to consider tidally energetic environment [45]), a power law coefficient $\alpha, h$ the water depth, $\bar{U}$ the depth average velocity and $z$ being the height above the seabed. It should be pointed out that this equation does not take into account wind and wave-driven surface effects which could alter the velocity profile [46,47].

\section{Validation}

Calibration, validation techniques used for the models and results for the baseline are outlined in this section.

\subsection{Calibration}

\subsubsection{Free Surface and Velocities}

The $2 \mathrm{D}$ and 3D models were calibrated against five ADCP measurements $(\mathrm{C} 1, \mathrm{CW} 2, \mathrm{CW} 3$, CW4 and CWTb1 / cf. Table 2) from the first AUSTEn campaign in March 2018. Calibration was performed by adjusting the seabed roughness with the Manning number $(\mathrm{M})$ in $2 \mathrm{D}$ and roughness height parameter in 3D, with seven tests to obtain the closest match of surface elevations, depth-averaged velocities (DAV) and velocity profiles between ADCP measurements and numerical model's predictions, as shown in Figure 4. The phase shift between predicted and measured timeseries was removed following the EMEC guidelines [43]. Taylor diagrams were used to rank model skill depending on surface elevation and current speed accuracy against the field measurements at the location of the five ADCPs. These Taylor diagrams allow visual comparison of three statistical metrics (Standard deviation, Correlation coefficient and Centered Root Mean Square) and provide a summary of the performance of each simulation. For both surface elevations and DAV, the runs $\mathrm{R} 4(\mathrm{M}=32)$ and 
R9 $(M=30)$ in 2D showed good agreement with the five ADCP data (Figure 4). Three dimensional models increase computational cost so only R4 and R9 and R6 (reference for lower quality) were compared, with R4 the closest to the measurements (Figure 5a). Further comparisons between R4 and R9 were performed, examining current speed at the hub height, velocity profiles (Ebb and Flood) and harmonic analysis of the principal constituent. Ebb direction was defined for this work as the tidal current going from Bass Strait to Tasman Sea (eastwards) and flood from Tasman Sea to Bass Strait (westwards). R4 and R9 showed similar results for the velocities at the hub height layer (Figure 5b,c).
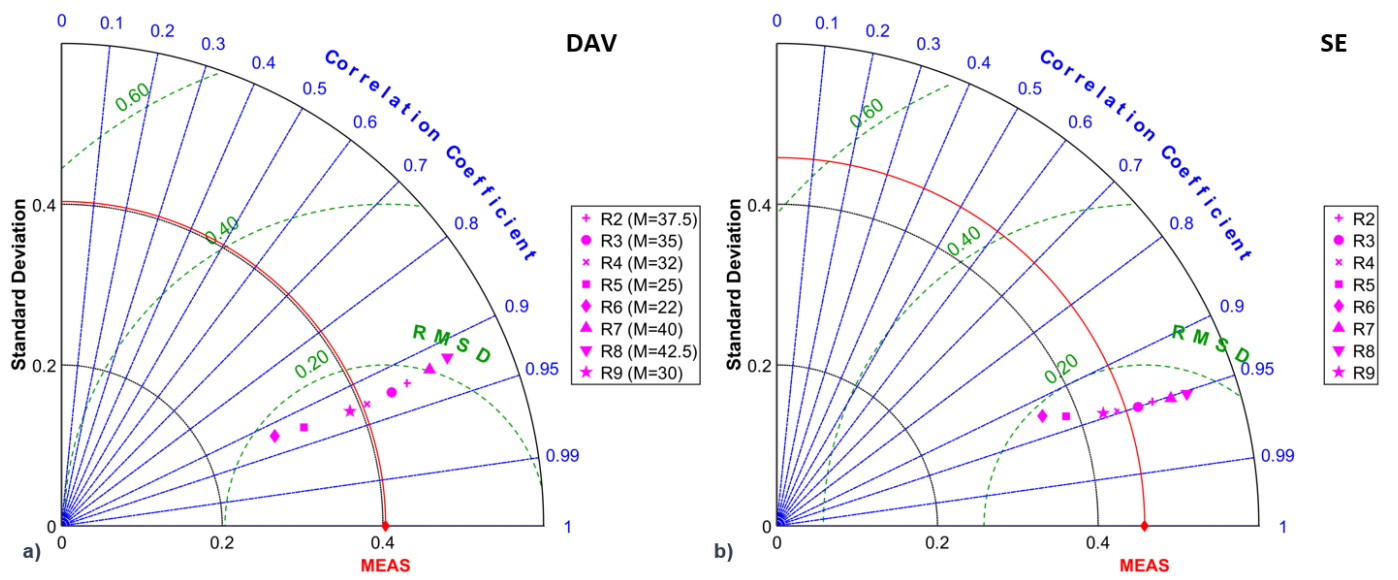

Figure 4. Taylor Diagrams for depth averaged velocities (left) and surface elevations (right) in 2D for 35 days for 5 stations (MEAS: measured values from ADCP; RMSD: Root-mean square deviation).
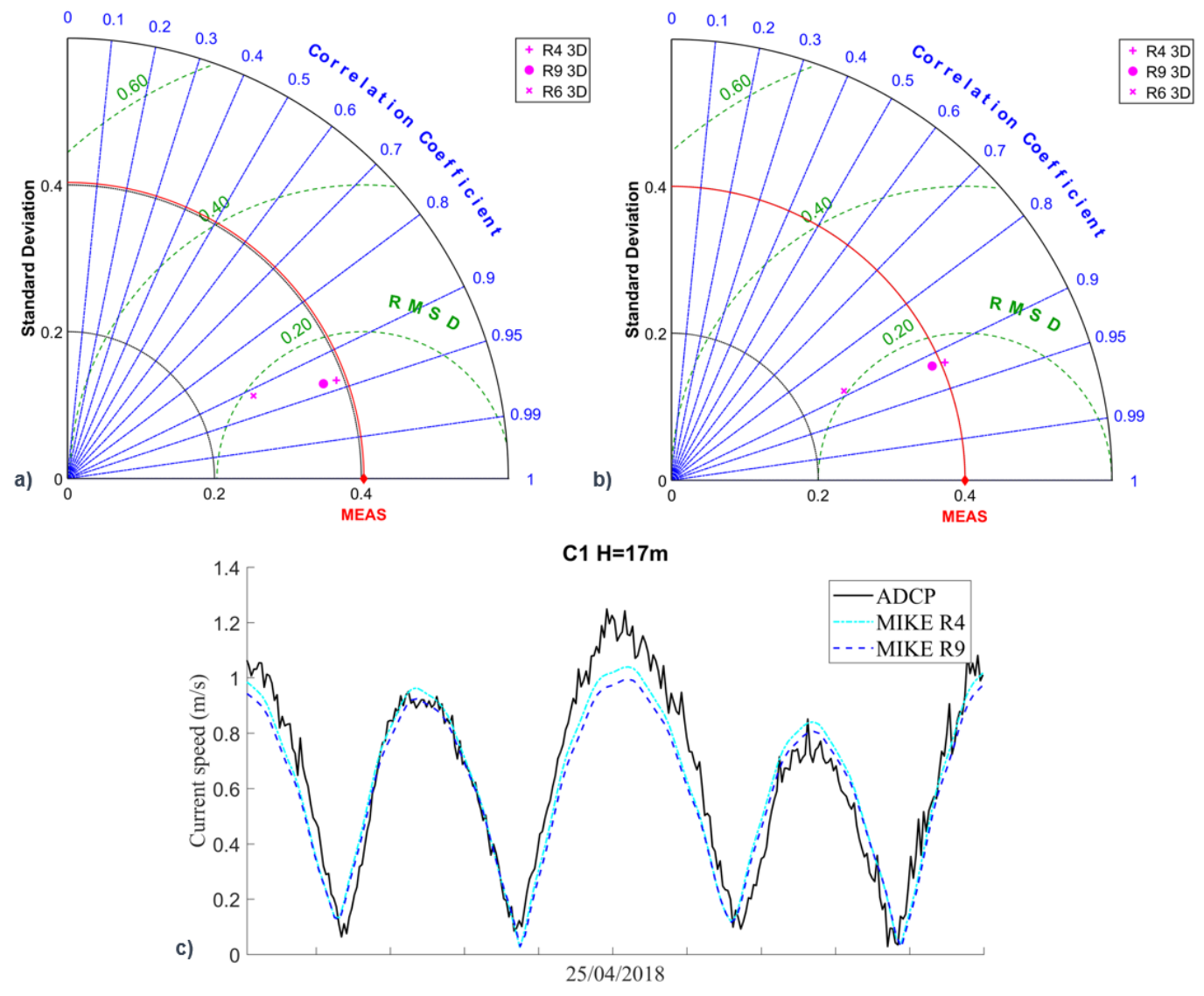

Figure 5. Taylor diagram for (a) depth averaged velocities in 3D for 35 days, (b) magnitude of velocities at the hub height in 3D for 35 days and (c) timeseries of velocities at the hub height in 3D for Acoustic Doppler Current Profiler C1 for 1 day. 
For velocity profiles, the data were decomposed in ebb and flood, with results showing good agreement with the five ADCP measurements (Figure 6). The models correlated well with all stations: both runs are pretty close to the measurements. The highest correlation between in situ data and numerical model was found for simulation run R4 at station CW2 deployed $2.2 \mathrm{~km}$ southwest of Clarke Island, CW4 deployed $7.5 \mathrm{~km}$ north of Swan Island and CWTb1 in the deep pocket at the eastwards entrance of the channel. Those results confirmed the ability of the model to represent accurately the vertical profile distribution of the velocity in Banks Strait.
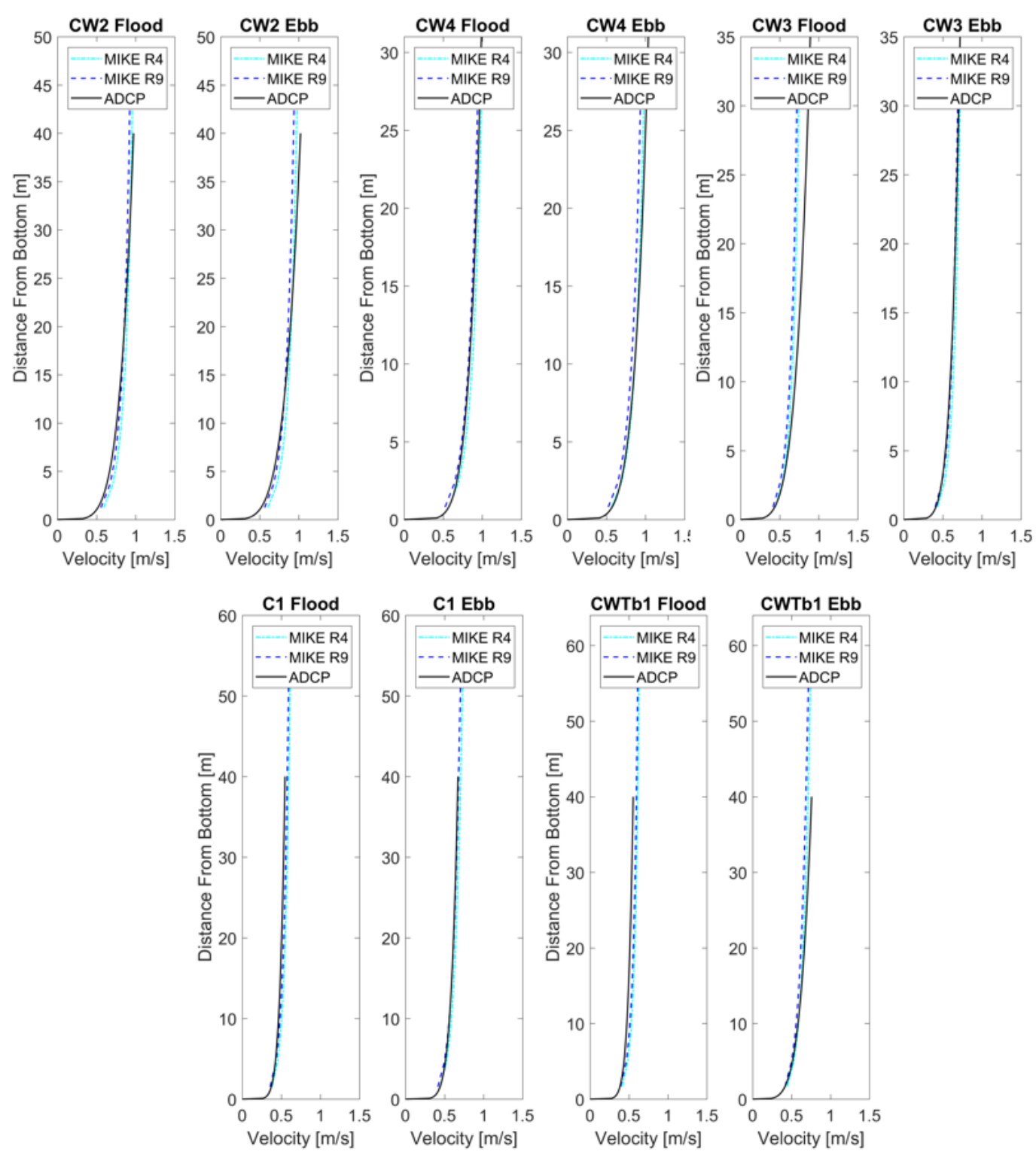

Figure 6. Calibration analysis for 3D current profiles for Ebb and Flood: Average for 35 days at the location of ADCP stations.

\subsubsection{Harmonic Analysis}

Harmonic constituents were derived from the timeseries of the 35 days simulations, the dominant harmonic constituent M2 was determined using the Matlab program UTide [48] from surface elevation and current velocities for both the MIKE models and the ADCP stations. The M2 constituents found were validated for both amplitude and phase for runs R4 and R9, with similar differences (Table 3). 
Table 3. Comparison between modelled and observed M2 constituents $(\mathrm{u}, \mathrm{v})$.

\begin{tabular}{ccccccccccc}
\hline & \multicolumn{4}{c}{ Phase for M2 (degree) } & \multicolumn{4}{c}{ Amplitude for M2 (m) } \\
\cline { 2 - 12 } & \multicolumn{4}{c}{ 3D } & \multicolumn{2}{c}{ 2D } & \multicolumn{3}{c}{ 3D } & \multicolumn{2}{c}{ 2D } \\
\hline Stations & OBS & R4 & R9 & R4 & R9 & OBS & R4 & R9 & R4 & R9 \\
\hline CW2 & 140 & 139 & 139 & 139 & 139 & 1.25 & 1.3 & 1.25 & 1.38 & 1.31 \\
CW3 & 118 & 125 & 125 & 125 & 125 & 0.99 & 0.97 & 0.93 & 1.03 & 0.97 \\
CW4 & 161 & 165 & 165 & 165 & 165 & 1.36 & 1.3 & 1.23 & 1.38 & 1.29 \\
C1 & 165 & 158 & 157 & 157 & 157 & 0.85 & 0.88 & 0.85 & 0.93 & 0.89 \\
CWTb1 & 158 & 154 & 153 & 154 & 153 & 0.88 & 0.91 & 0.88 & 0.96 & 0.92 \\
\hline
\end{tabular}

\subsubsection{Validation}

Among all comparisons, $\mathrm{R} 4$ had the highest correlation for both 2D and 3D depth average velocities and velocity profiles, therefore it was chosen to represent the conditions in Banks Strait. The run $\mathrm{R} 4$ was then run for one year in 2D and validated against measurements for three different periods with different ADCP: Autumn (22/03/2018-09/07/2018) with C1, CW2 and CWTb1; Winter (13/07/2018-06/09/2018) with CW1, CW2 bis and CW4 bis and Summer (06/12/2018-15/02/2019) with C1 bis. These large validation datasets give confidence in the ability of the model to reproduce tidal currents in Banks Strait. All periods showed good correlation for DAV, with slightly lower quality results for Winter period with a correlation coefficient of 0.86 (Figure 7). To evaluate the influence of waves on simulation accuracy in Winter, a small subset of the data was analysed: a period of smaller significant wave height in Winter (31/07/2018 to 06/08/2018) was considered from the measurements of waves for CW4 bis, leading to a better correlation coefficient: $\mathrm{R}=0.9$. The $2 \mathrm{D}$ models were also validated using data available for tidal range from the Australian Baseline Sea Level Monitoring Project [49] for the following stations: Portland (141.6136, -38.3439), Lorne (143.9889, -38.3439), Burnie (145.9149, -41.05) and Spring Bay (147.9308, -42.5464 ). Comparisons over 35 days found average correlation coefficient $R=0.95$ (minimum at 0.9 ) indicating good agreement with the measured data.

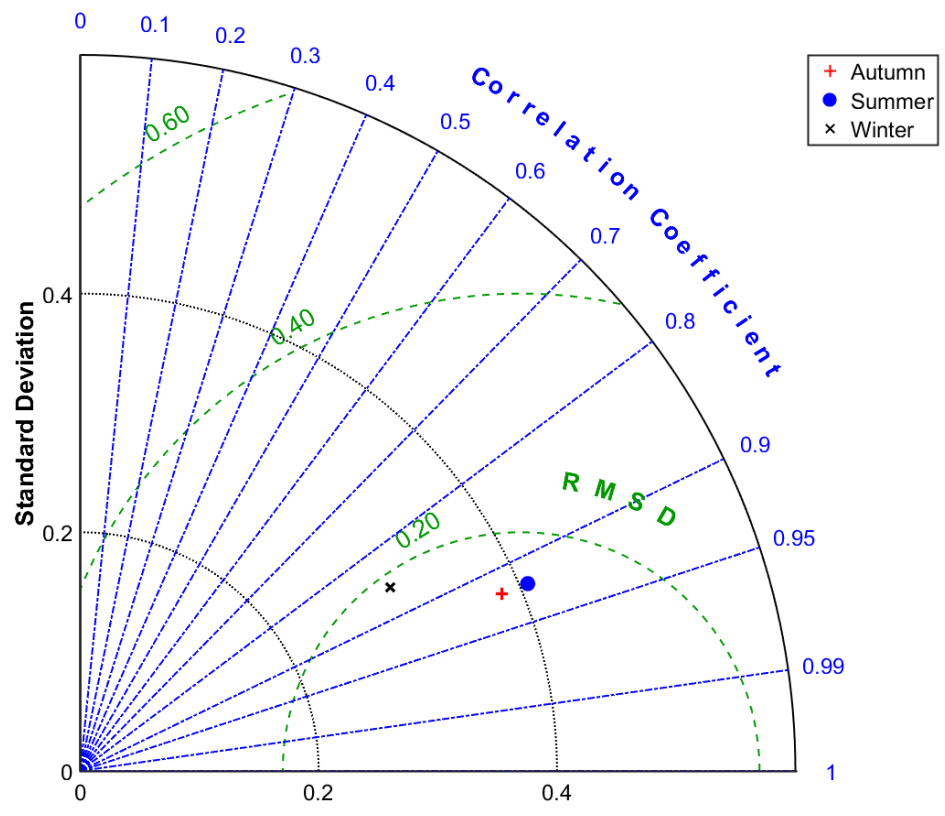

Figure 7. Taylor diagram for depth average velocities between ADCP stations (localisation on Figure 2) and 2D MIKE results (March 2018-February 2019). 


\subsection{The Hydrodynamics in Banks Strait: Baseline Results}

The models were applied to develop a baseline case with no tidal turbine and hence no tidal energy extraction to evaluate the current circulation in the strait and determine suitable locations for the placement of tidal turbine farms. Similar to previous studies where the strongest currents were found in the middle of the channel south of Clarke Island [18], the 3D model results reveal mean current speeds of $1.2 \mathrm{~m} / \mathrm{s}$ and maximum speeds of $2.5 \mathrm{~m} / \mathrm{s}$ located at (596878/-4498311 UTM 55) for the period of 22/03/2018 to 26/04/2018 (dataset of 35 days). The average maximum for the mid water column is illustrated in Figure 8 for two spring-neap cycles, with the time series of current speed at the surface for one spring-neap cycle at the location of the maximum of velocity. The modelled currents displayed 2 eddies near the area of strong currents: with one at the vicinity of the sand dunes, the presence of this feature could be strongly linked to this eddy (Figure 9).

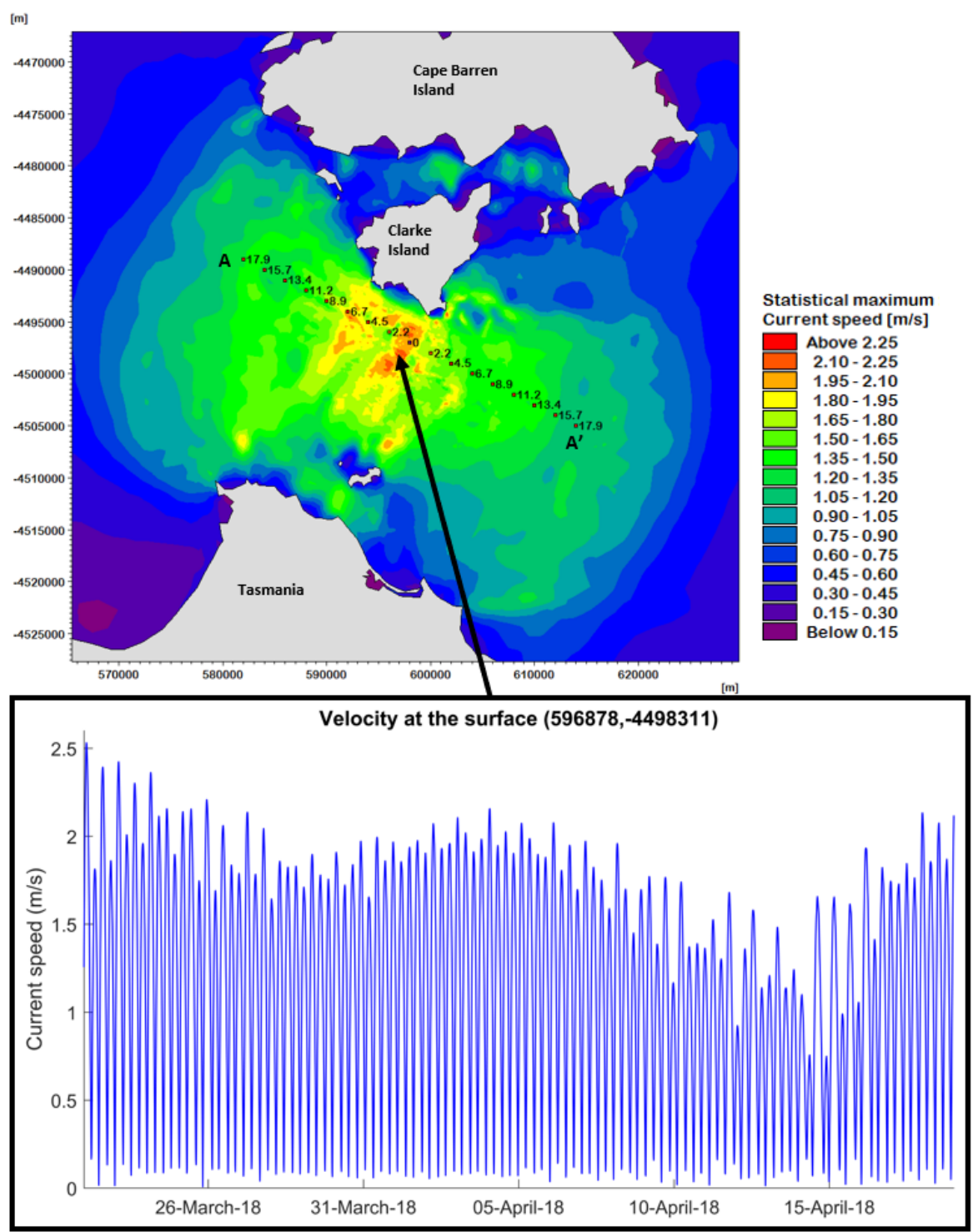

Figure 8. At the top: Statistical maximum for current speed over two spring-neap cycles at the mid water column with the location of the profile $\mathrm{AA}^{\prime}$ (distance from location of tidal farm in $\mathrm{km}$ ) for the baseline case. At the bottom: Current speed at the location of a possible tidal farm (596878, -4498311 /UTM 55) over two spring-neap cycles for the 3D baseline case at the surface (no tidal energy extraction). 


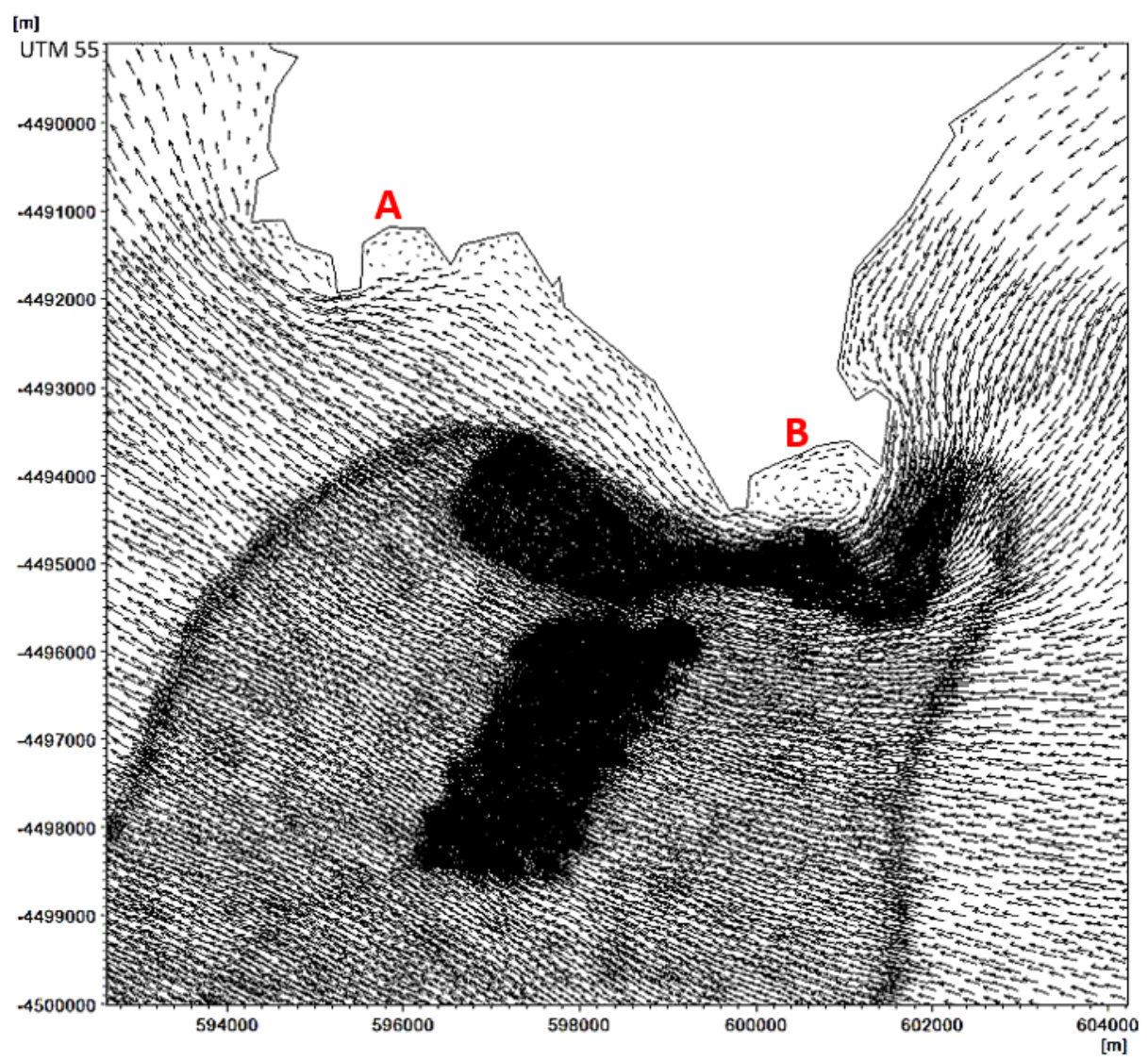

Figure 9. Spatial distribution of current direction near the area of strong currents around peak Flood. A and B highlight the presence of eddies near the area of interest.

\section{Influence of the Tidal Farms on the Hydrodynamics}

To evaluate the influence of tidal farms on the hydrodynamics (current speed, bed shear stress), simulations were performed comparing the spatial influence of two tidal farms between 2D and 3D, the influence near the seabed and the hydrodynamic influence on sand dunes near Clarke Island to evaluate potential disturbance in the ecologic system. The tidal farms are located south of Clarke Island where the strongest currents were found and where the bathymetry did not exceed $50 \mathrm{~m}$ (operational water depth).

\subsection{Comparison of Model Spatial Extent 2D/3D}

Simulations were performed in 2D and 3D in Banks Strait with and without tidal farms of 100 turbines (TF100) and 300 turbines (TF300). The spatial extent of the difference in mean current speed over 35 days between the baseline (no tidal energy extraction) and the scenario TF100 was limited to less than $5 \mathrm{~km}$ from the tidal farm location for both 2D and 3D DAV (Figure 10a,c). For the TF300 scenario, changes in mean current speed were found to exceed to more than $7 \mathrm{~km}$ (Figure 10b,d). The change in mean current speed was greatest at the location of the farms due to the removal of energy by tidal turbines. For the TF300 case in 2D and 3D, a slight increase of the current speed $(0.04 \mathrm{~m} / \mathrm{s})$ is noticed between the farm and Clarke Island where sand dunes are present, and also south of the tidal farm, resulting from the barrier effect of the turbines on the flow. In both models (2D/3D), the scenario TF100 (Figure 10a,c) had less influence on the reduction of current speed than the scenario TF300: a maximum of $0.05 \mathrm{~m} / \mathrm{s}$ against $0.12 \mathrm{~m} / \mathrm{s}$ for TF300 (Figure 10b,d). The values are quite similar between $2 \mathrm{D}$ and $3 \mathrm{D}$, the major difference is the spatial extent where $2 \mathrm{D}$ displays a larger influence which could be considered as a conservative measure. For more insight about the difference between the two arrays, the mean current speed over 35 days was extracted at the mid 
water column in the 3D scenario (Figure 11). The influence of tidal energy extraction is higher at the location of the turbines for the TF300 scenario: above $0.2 \mathrm{~m} / \mathrm{s}$ reduction against around $0.1 \mathrm{~m} / \mathrm{s}$ for TF100. These results are slightly lower than [5] who found a mean reduction of $0.3 \mathrm{~m} / \mathrm{s}$ with a farm of 290 turbines in the Alderney Race.
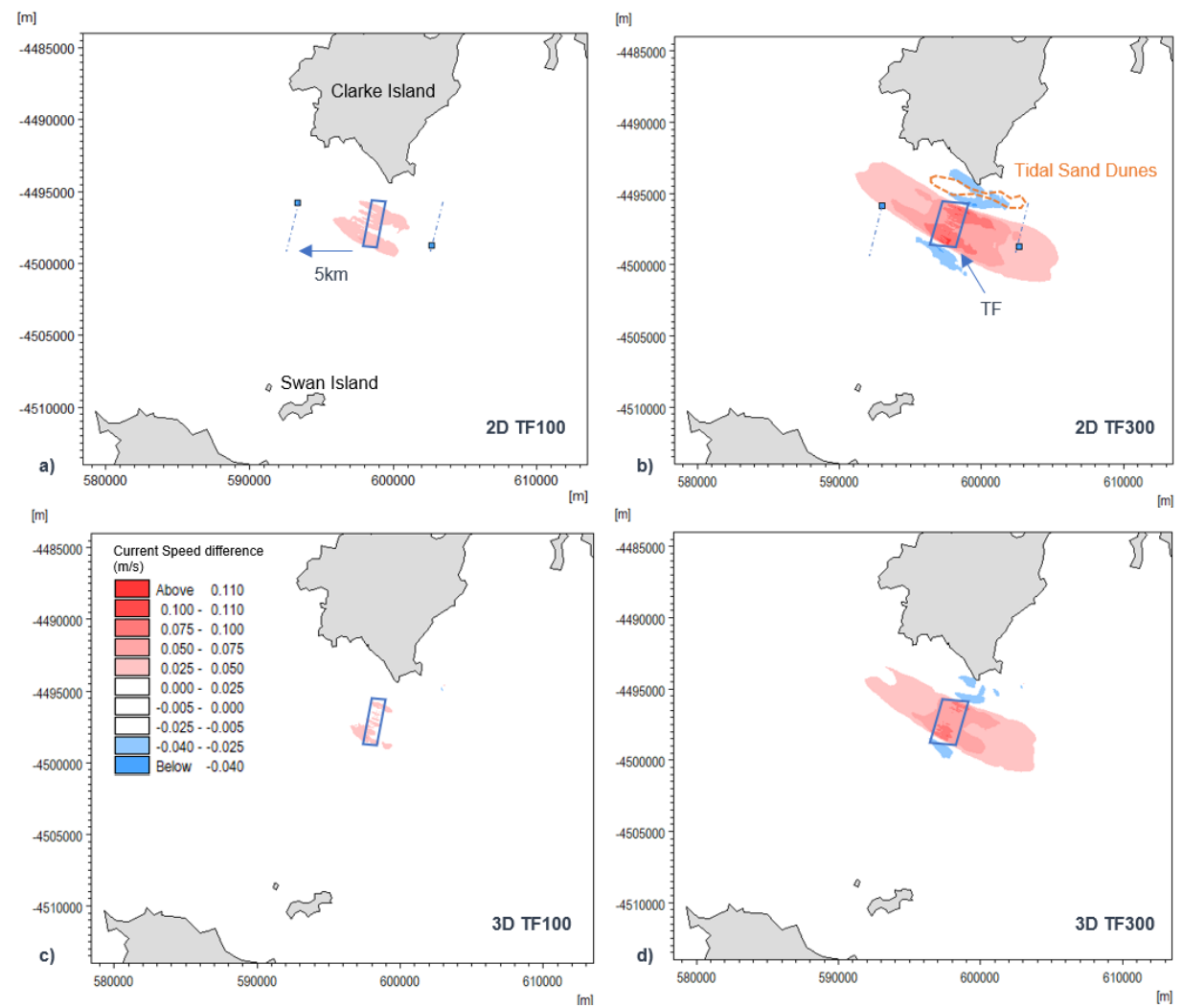

Figure 10. Difference in depth average velocities between Baseline and scenarios with tidal farm in 2D $(\mathbf{a}, \mathbf{b})$ and $3 \mathrm{D}(\mathbf{c}, \mathbf{d})$ over 35 days. Negative reduction compared to the baseline is shown in blue (corresponding to increase of velocity) and positive reduction in red (corresponding to a deficit in velocity). (Legend valid for all maps/dashed lines with blue squares represent $5 \mathrm{~km}$ limit from the tidal farm).

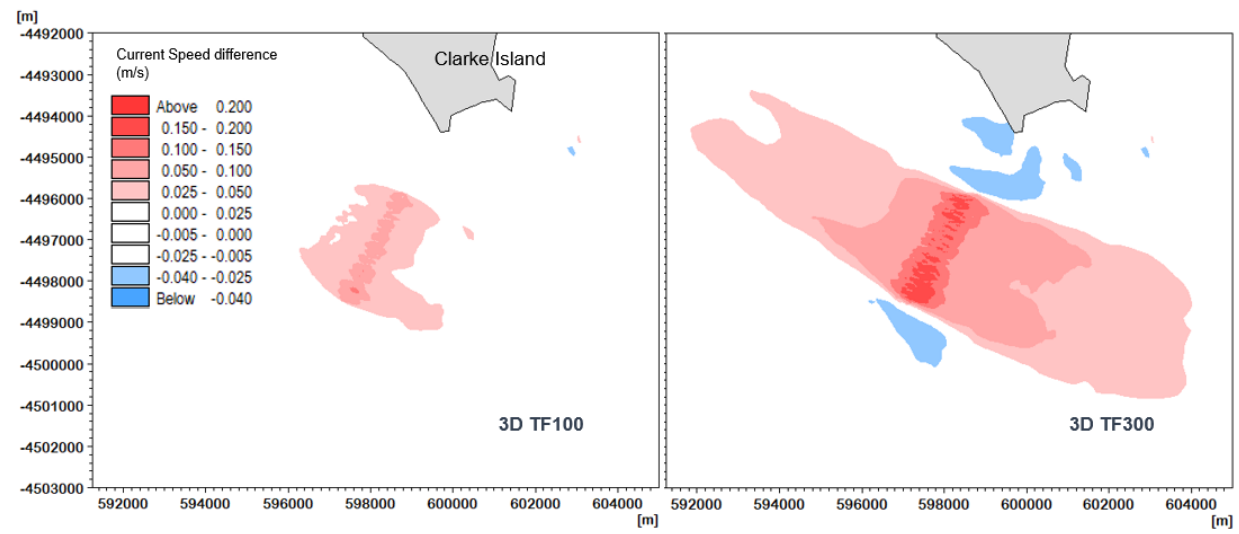

Figure 11. Difference in mean current speed over 35 days between the baseline and scenarios with tidal farm at the mid water column in 3D showing the effect of tidal energy extraction. Negative reduction compared to the baseline is shown in blue (corresponding to increase of velocity) and positive reduction in red (corresponding to a deficit in velocity). 
A profile AA' (location on Figure 8) parallel to the direction of the currents was extracted to examine the spatial influence of the tidal farms on depth averaged velocities for the 35 days dataset in 2D and 3D (Figure 12). The drop for the baseline case at $2 \mathrm{~km}$ is caused by the presence of a canyon. The 2D model baseline results for current speed were overall $5 \%$ higher than the 3D DAV results, corresponding to an increase of approximately of $0.05 \mathrm{~m} / \mathrm{s}$ along the profile. A significant drop in current speed was noticed for both farms at their location, with a greater reduction for the scenario TF300 as expected due to higher levels of tidal energy extraction, equivalent to a reduction of $7 \%$ in the $3 \mathrm{D}$ model (Figure 12). For both dimensions, the differences were lower at approximately $13 \mathrm{~km}$ from the tidal farm reducing to less than $1 \%$ up to $0 \%$ at $18 \mathrm{~km}$ towards the Tasman Sea for the two tidal farms (Table 4). The influence of the 100 turbine array was minimal in the near field with less than $1 \%$ of difference in mean current speed. For smaller scale tidal farm development, this is a positive outcome.
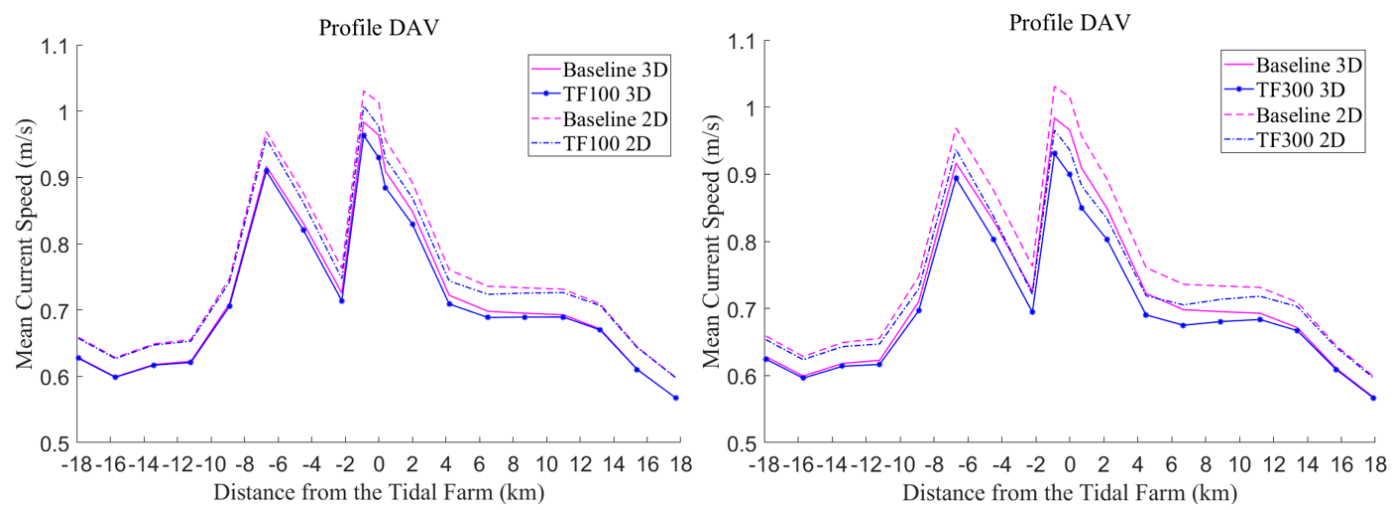

Figure 12. Comparison of depth averaged velocities at the profile $\mathrm{AA}^{\prime}$ (location Figure 8) for an average of 35 days.

Table 4. Change in magnitude of current speed along the profile for tidal farm TF100 \& TF300 over 35 days.

\begin{tabular}{ccccc}
\hline & \multicolumn{3}{c}{ Difference in DAV } \\
\cline { 2 - 5 } & \multicolumn{2}{c}{ TF300 } & \multicolumn{2}{c}{ TF100 } \\
\hline Distance From Tidal Farm (km) & 3D & 2D & 3D & 2D \\
\hline 0 & $7.39 \%$ & $8.44 \%$ & $3.67 \%$ & $3.69 \%$ \\
4.5 & $4.06 \%$ & $5.21 \%$ & $1.55 \%$ & $1.94 \%$ \\
9 & $2.05 \%$ & $2.64 \%$ & $0.73 \%$ & $0.92 \%$ \\
13.4 & $0.67 \%$ & $0.92 \%$ & $0.19 \%$ & $0.31 \%$ \\
18 (towards Bass Strait) & $0.62 \%$ & $0.84 \%$ & $0.18 \%$ & $0.26 \%$ \\
18 (towards Tasman Sea) & $0.21 \%$ & $0.35 \%$ & $0 \%$ & $0 \%$ \\
\hline
\end{tabular}

For 2D models, the difference in the magnitude of velocity between the baseline and scenarios with tidal farms was greater than in 3D DAV at the vicinity of the arrays, however in the far field the average difference was the same. The 2D model results match the 3D DAV results for the TF100 scenario with a maximum difference of $0.4 \%$ and are similar in the far field for the TF300 scenario (Table 4). The 2D models overestimated slightly the current speed compared to the 3D DAV results, with the difference between baseline and scenario with turbines highest at the location of the TF300. This should be considered if a preliminary resource assessment is performed in 2D. At the location of the tidal turbines, the velocities difference between 2D/3D reached an average of $0.1 \mathrm{~m} / \mathrm{s}$ corresponding to $12 \%$, which is lower than the results of [13] who found a $20 \%$ difference in an idealised channel similar to Pentland Firth. However, the difference between 2D and 3D DAV was found to be negligible in the far field of the tidal farms.

Small discrepancies were observed between 2D and 3D models in the near and far field. Given the high computational cost required by 3D models, the authors recommend that preliminary assessments 
be performed in 2D. These results are in accordance to previous studies in an idealised channel for the difference of dimension with a focus on the bed level change. The 2D models are a good compromise between model accuracy and time management, especially for long temporal scale assessments for a first approximation.

\subsection{Influence Near the Seabed}

To enable comparisons of the 2D model to the 3D model at turbine hub heights, the power law defined in Equation (1) Section 2.3 was used. Previous studies have demonstrated that the 1/7th power law $(\alpha=7)$ is generally the most suitable to capture vertical processes in coastal oceanographic research; moreover, [45] showed that $\alpha=7$ correlated well with tidal energy sites conditions in the Irish Sea. However, guidelines [43,50,51] and field data observation [52] recommend a 1/10th power law in tidal energetic sites. To examine the influence of power law factors on simulation results, two $\alpha$ coefficients ( 7 and 10$)$ were analysed with the velocity profile for four points (inside the tidal farm then at $0.9,4.5$ and $18 \mathrm{~km}$ from the tidal farm towards Bass Strait) for the TF300 model as shown in Figure 13. Results indicated that the 1/10th power law correlated the best with 3D results, as the difference was $14 \%$ instead of $25 \%$ for the $\alpha=7$ model. There was a significant difference of velocity at the location of the tidal farm between 2D and 3D. The 3D model represented well the decrease of the flow in the water column due to the presence of the turbines. This velocity deficit at the hub height cannot be reproduced in the 2D model with the power law and thus lead to a misrepresentation of the current speed in 2D at the location of the tidal farm confirming the findings of [13]. It should also be noted that some tidal energy sites have more complex velocity profiles which do not fit the power law equation [53]. Future research using coupled hydrostatic and non-hydrostatic models will be able to capture flow properties at scale ranging from ocean to tidal turbines blades enabling the accurate modelling of all hydrodynamics flow properties including wake environment and velocity profiles.
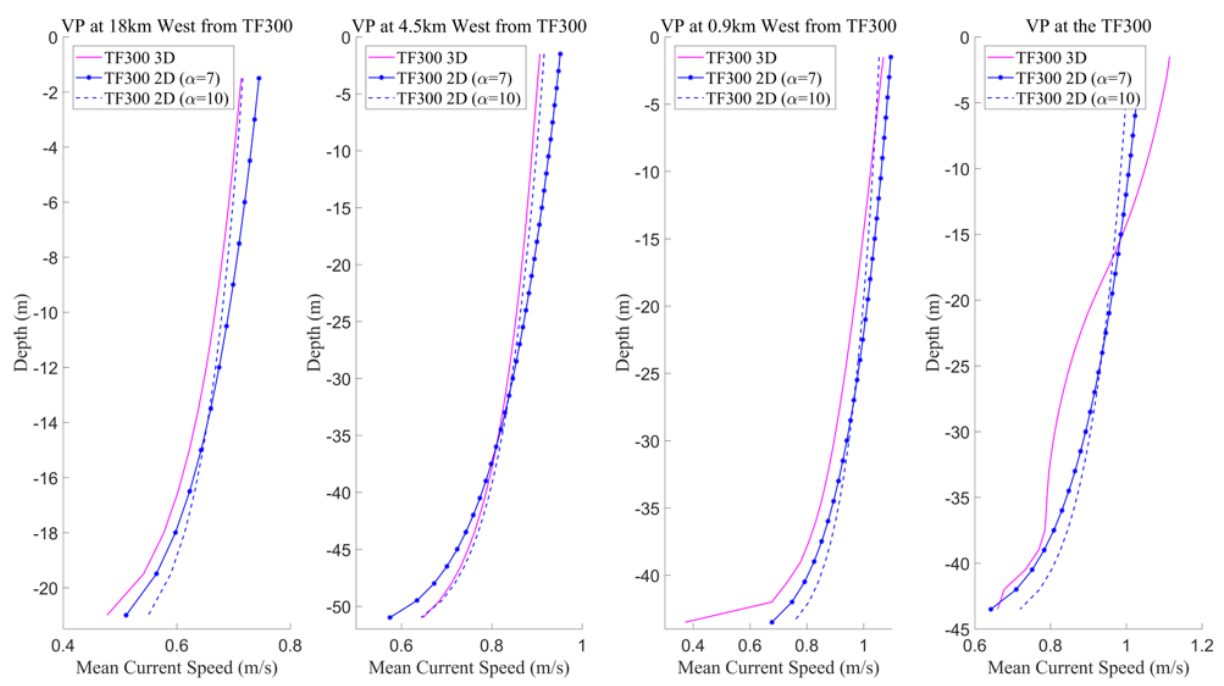

Figure 13. Velocity profile comparison due to uncertainty of alpha. The power law for four points of the profile $\mathrm{AA}^{\prime}$ (location on Figure 8 ) showing velocity deficit at the location of the tidal farm.

Friction between the near seabed currents and the seafloor creates a layer of shear and increased turbulence above the seabed called the bottom boundary layer. This is the layer where the flow is the most influenced by the seafloor and alterations in this layer could lead to significant impact in sediment transport patterns. The profile $\mathrm{AA}^{\prime}$ was extracted at the bottom layer for the mean current speed (Figure 14a,b) with a coefficient $\alpha$ equal to 10 for the power law. An increase of current speed was noticed at the location of the tidal farm only for the 3D models: with magnitudes of $1 \mathrm{~cm} / \mathrm{s}$ for TF100 and $3 \mathrm{~cm} / \mathrm{s}$ for TF300 ( $2 \%$ and 5\%, respectively) found. Away from the tidal farm, the reduction in current speeds are quite similar for 2D and 3D: for TF300 $6 \%$ and $5.6 \%(3 \mathrm{D}, 2 \mathrm{D}$, respectively) and $2 \%$ 
for TF100 at $2.2 \mathrm{~km}$ from the tidal farm. The differences fade away in the far field reaching less than $1 \%$ at $13.4 \mathrm{~km}$ for both dimensions. The 3D models appear to model the acceleration caused by the constriction of the flow beneath the turbines, which the 2D models cannot capture.
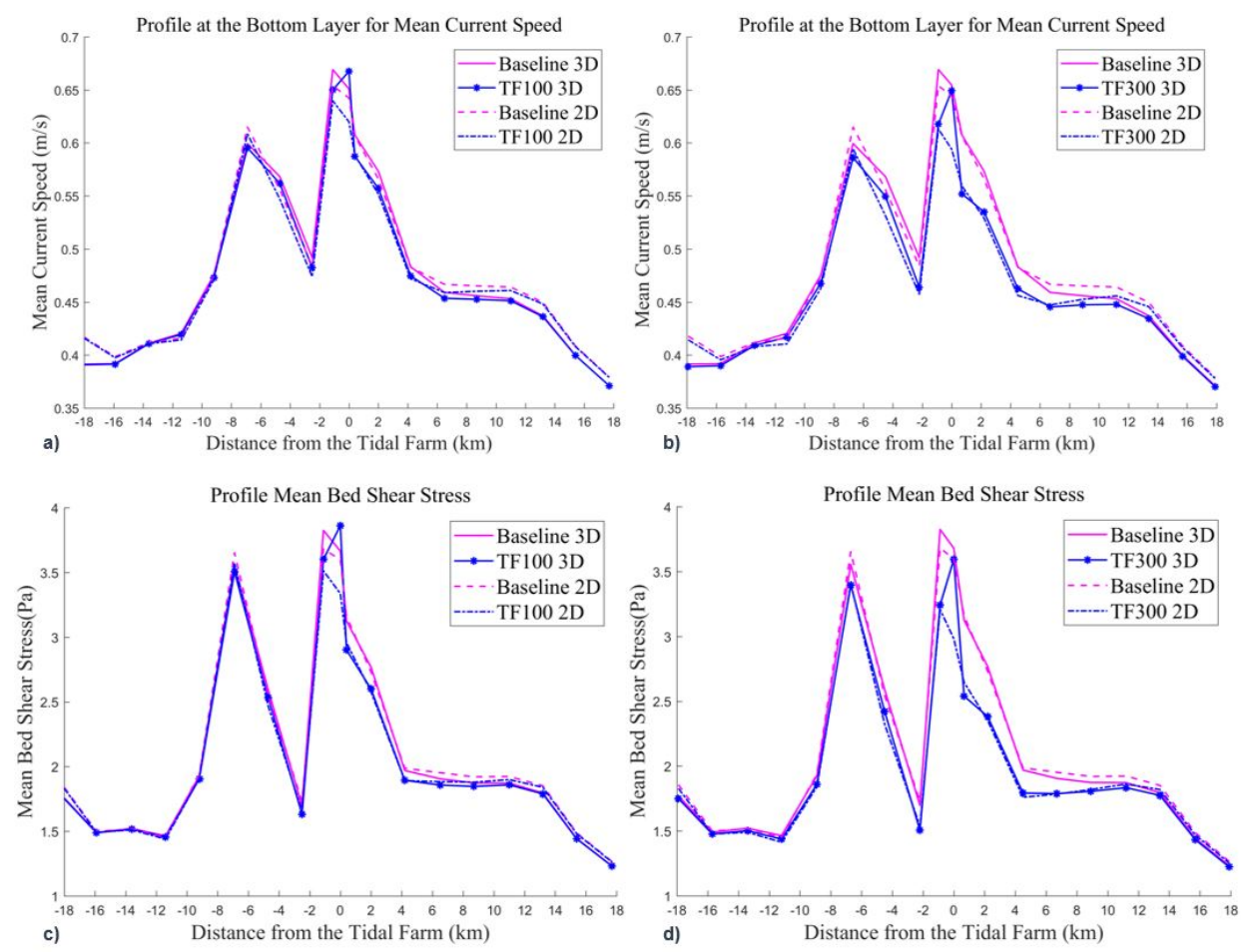

Figure 14. Change in magnitude velocity at the bottom layer $(\mathbf{a}, \mathbf{b})$ and in the bed shear stress (c,d) due to energy extraction over 35 days between baseline and TF scenarios in 2D and 3D at the profile AA.

In the 2D model, the bed shear stress is derived from the DAV velocities, whereas the bed shear stress is determined from the bottom cell velocity in the 3D model; therefore, the profile for the bed shear stress followed the same fluctuation as in the bottom layer in 3D with an increase at the location of tidal farm (Figures 14c,d and 15). Around the tidal farms the bed shear stress was reduced by $7 \%(0.22 \mathrm{~Pa})$ for TF100 arrays in 3D, $6 \%$ for $2 \mathrm{D}$, with the differences not significant in the far field. The reduction of bed shear stress for the TF300 scenario was greater reaching $20 \%$ (equivalent to $0.58 \mathrm{~Pa})$ around the tidal farm in 3D and $15 \%(0.51 \mathrm{~Pa})$ in $2 \mathrm{D}$. The 2D results were similar to the 3D results for the scenario TF100 and TF300 in the far field. These results vary compared to the influence of turbines in Ramsey Sound as shown by [7] who found an average reduction of $2.3 \mathrm{~Pa}$ in the Ramsey sound with less devices. The peak reduction found here is $0.9 \mathrm{~Pa}, 25$ times lower than [4] with $25 \mathrm{~Pa}$ in the Pentland Firth. These discrepancies can be explained by the faster flows occurring in these two sites and therefore a greater alteration in hydrodynamics. Influence on bed shear stress was observed with the TF100 scenario and was greater with the 300 turbines arrays with a spatial influence of $7 \mathrm{~km}$ instead of $4.5 \mathrm{~km}$ for TF100 (Figure 15), results close to the spatial extent of $12 \mathrm{~km}$ found by [7]. Reduction in the bed shear stress around the tidal farm suggests that accretion of sediments may appear and change the dynamics in the channel as it can be seen on maps on Figure 15. The increase of bed shear stress at the location of the farm and at the top and bottom suggest that additional scour and more erosion could occur at the location of the sand dunes between the tidal farm and Clarke Island. 


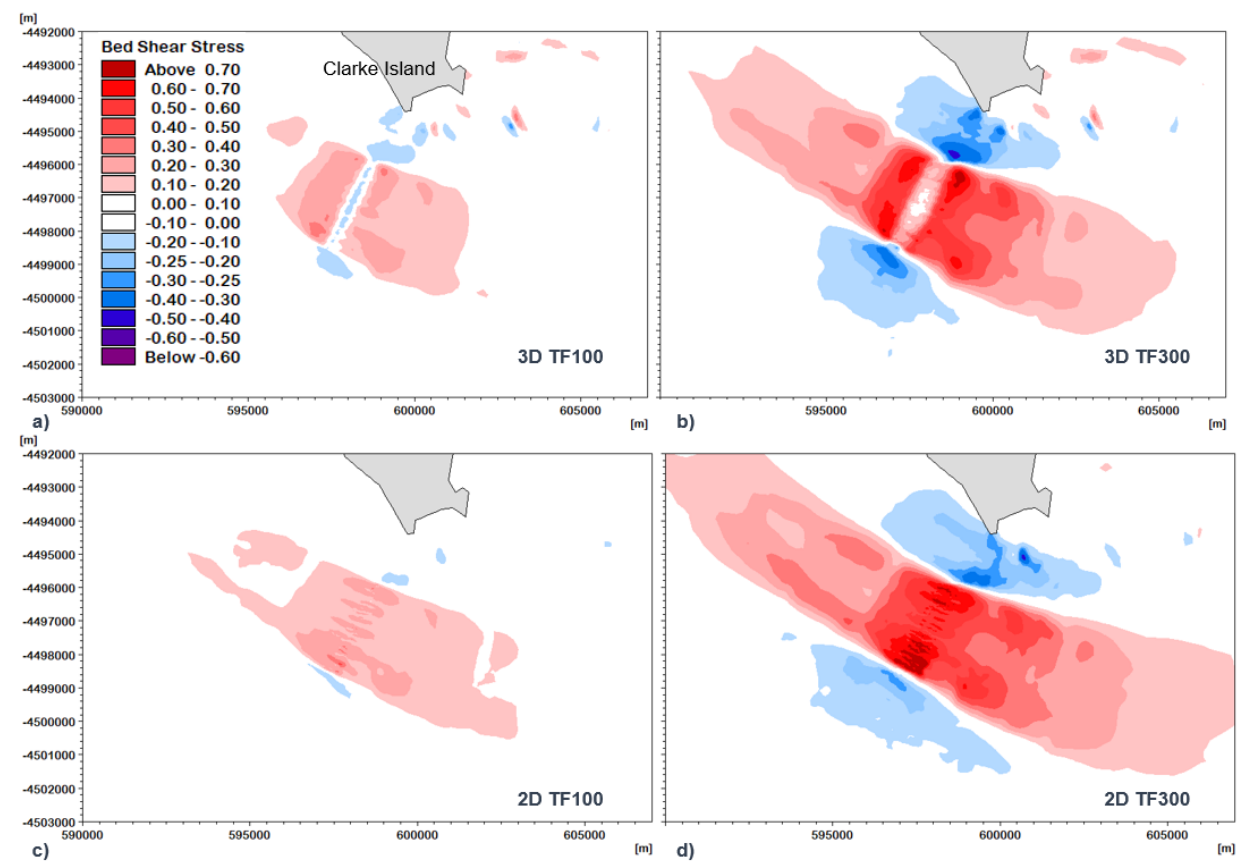

Figure 15. Change in the magnitude of bed shear stress $(\mathrm{Pa})$ between baseline and TF scenarios in $3 \mathrm{D}(\mathbf{a}, \mathbf{b})$ and $2 \mathrm{D}(\mathbf{c}, \mathbf{d})$.

A closer look was given to the region of the sand dunes near Clarke Island given the proximity to a potential tidal farm. Alteration in current speed and bed shear stress could lead to a disturbance of the benthic ecology system. Bed shear stress results in 3D and 2D were compared between the case with no tidal extraction and the two scenarios TF100 and TF300 (Figure 16). The change in the magnitude for the 100 turbines arrays was less than $0.12 \mathrm{~Pa}$ and less than $0.26 \mathrm{~Pa}$ for the 300 turbines case for both 2D/3D. The difference between 2D and 3D results were not significant: a maximum of $4.5 \%$ difference with an average difference around $0.06 \mathrm{~Pa}$ for all the scenarios, but the models did not display the same fluctuations. The slight change in bed shear stress at this location needs to be better understood, with more studies on the dynamics of these sand dunes. To pursue the EIA, the focus needs to be on the dynamics of sediment, especially at the location of the sand dunes which are of economic importance. They may provide sediment for the close beaches of Clarke Island, protect them from erosion during storms and may contribute to the fishing industry being a source of nutrients for many fish species [54,55].

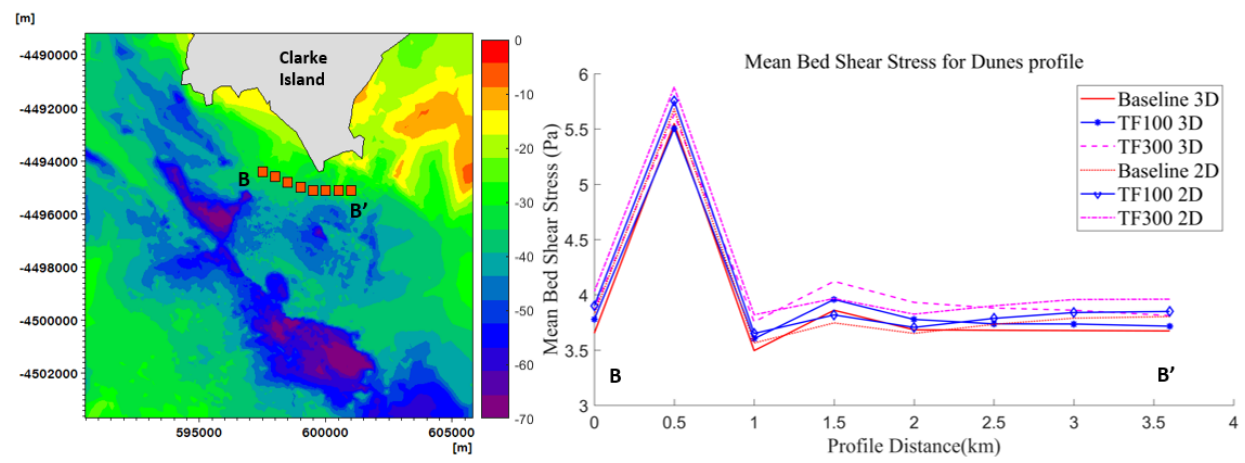

Figure 16. Location of the profile $\mathrm{BB}^{\prime}$ with bathymetry $(\mathrm{m})$ of the area, Right: mean bed shear stress over 35 days for the profile $\mathrm{BB}^{\prime}$ in the sand dunes area for all $3 \mathrm{D} / 2 \mathrm{D}$ scenarios.

These results reinforces previous findings $[7,8]$ that, for preliminary assessment of oceanographic changes of a potential tidal energy sites, 2D models are suitable for examining far field parameters 
(current speed and bed shear stress). These 2D studies can give a first insight of the potential influence of arrays on a longer time frame given the reduced computational costs when compared to 3D models. Thus, 2D models are assets for the dynamics of sediment transport and are an effective tool to understand the influence of the removal of energy. However further work is needed to understand the capability of 2D models with more complex and challenging scenarios such as sand dunes migration. $3 \mathrm{D}$ models remain essential to have more insight at the location of tidal farm; however, they become less powerful in the near and far field as it gives similar results as the 2D model in terms of hydrodynamic environmental influence.

\section{Conclusions}

The hydrodynamics of Banks Strait was examined using two high resolution models in 2D and $3 \mathrm{D}$, with resolution varying from $3 \mathrm{~km}$ to $20 \mathrm{~m}$ in the area of interest to simulate the presence of tidal farms. The developed models were successfully validated against a large dataset of ADCP field measurements, with results indicating good agreement for surface elevation, depth average velocities and velocity profiles. Validation for a full year was then performed for the 2D model with close agreement to the field data found. Those results gave confidence in the ability of these models to reproduce the hydrodynamics in Banks Strait.

The implementation of tidal turbines in the numerical models showed the footprint effect of tidal turbines on the hydrodynamics (current speed, bed shear stress). Scenario with 100 turbines showed minimal influence on the velocities in the near field, with changes in velocity only found less than $3 \mathrm{~km}$ from the farm. For the alteration of bed shear stress, this scenario did not display any significant difference compared to the baseline, which is a relatively good outcome for the deployment of a small tidal farm. The spatial influence of the 300 turbines farm was greater reaching $7 \mathrm{~km}$ from the farm for the difference in the current speed. A small number of devices will not change the system in a significant way compared to the natural variability; but, as these studies have shown, large scale arrays have the potential to influence the natural process. These alterations can lead to greater changes on the dynamics of sediments.

In the far field, the difference between the two dimensions 2D/3D was negligible, confirming that 2D models are suitable for investigating the influence of tidal arrays for a preliminary environmental assessment. At the location of the tidal farm 2D models were found to have slightly higher values for the influence of tidal energy extraction and thus precaution should be taken for resource assessment. Regarding local features here in Banks Strait, more work is needed to fully understand the effect of the tidal arrays on the sand dunes compared to the natural variability.

The findings of this paper are a first step in the understanding of the influence of tidal energy extraction in Banks Strait and gave a solid basis to reduce the uncertainty in the hydrodynamics for future investigation of sediment transport in the region. Future work will focus on the creation and calibration of a sediment transport model with in situ data (multi-beam, echosounder, bottom grabs, sediment traps and sub-bottom data) collected by the AUSTEn project. The migration of sand dunes will also be of a high interest to better understand the influence of anthropogenic activities on the physical environment.

Author Contributions: C.A., conceptualization, methodology, investigation, software, formal analysis, validation, writing — original draft, visualization; P.M., supervision, software, conceptualization, writing — review and editing; J.-R.N., supervision, project administration, funding acquisition, writing—review and editing; R.C., supervision, funding acquisition, writing-review and editing; I.P., writing-review and editing, funding acquisition. All authors have read and agreed to the published version of the manuscript.

Funding: The AUSTEn project is co-funded by the Australian Renewable Energy Agency through the Advancing Renewables Programme (grant G00902), the Australian Maritime College (University of Tasmania), the University of Queensland, CSIRO, our industry partners MAKO Tidal Turbines, Sabella SAS and SIMEC Atlantis Energy. 
Acknowledgments: The authors wish to acknowledge DHI for their role providing MIKE21/3 software throughout this PhD research, and for their support especially Méven Huiban. The authors are also grateful to Camille Couzi for the process of the ADCP. The authors also would like to acknowledge the support of IMAREST through the award "Laurie Prandolini Research Fellowship" given to this study.

Conflicts of Interest: The authors declare no conflict of interest.

\section{Abbreviations}

The following abbreviations are used in this manuscript:

$\begin{array}{ll}\text { ADCP } & \text { Acoustic Doppler Current Profiler } \\ \text { AEP } & \text { Annual Energy Production } \\ \text { AHS } & \text { Australian Hydrography Service } \\ \text { ARENA } & \text { Australian Renewable Energy Agency } \\ \text { AUSTEn } & \text { Australian Tidal Energy } \\ \text { AWAC } & \text { Acoustic Waves And Current Profiler } \\ \text { CSIRO } & \text { Commonwealth Scientific and Industrial Research Organisation } \\ \text { CTD } & \text { Conductivity Temperature Depth } \\ \text { DAV } & \text { Depth Average Velocities } \\ \text { EIA } & \text { Environmental Impact Assessment } \\ \text { EMEC } & \text { European Marine Energy Centre } \\ \text { IEC } & \text { International Electrotechnical Commission } \\ \text { IMOS } & \text { Integrated Marine Observing System } \\ \text { TF } & \text { Tidal Farm }\end{array}$

\section{References}

1. OES. Ocean Energy System Annual Report: An Overview of Ocean Energy Activities in 2019; OES: Paris, France, 2019.

2. Neill, S.P.; Litt, E.J.; Couch, S.J.; Davies, A.G. The impact of tidal stream turbines on large-scale sediment dynamics. Renew. Energy 2009, 34, 2803-2812. [CrossRef]

3. Frid, C.; Andonegi, E.; Depestele, J.; Judd, A.; Rihan, D.; Rogers, S.I.; Kenchington, E. The environmental interactions of tidal and wave energy generation devices. Environ. Impact Assess. Rev. 2012, 32, 133-139. [CrossRef]

4. Martin-Short, R.; Hill, J.; Kramer, S.; Avdis, A.; Allison, P.; Piggott, M. Tidal resource extraction in the Pentland Firth, UK: Potential impacts on flow regime and sediment transport in the Inner Sound of Stroma. Renew. Energy 2015, 596-607. [CrossRef]

5. Thiébot, J.; Bailly du Bois, P.; Guillou, S. Numerical modeling of the effect of tidal stream turbines on the hydrodynamics and the sediment transport-Application to the Alderney Race (Raz Blanchard), France. Renew. Energy 2015, 75, 356-365. [CrossRef]

6. Fairley, I.; Masters, I.; Karunarathna, H. The cumulative impact of tidal stream turbine arrays on sediment transport in the Pentland Firth. Renew. Energy 2015, 80, 755-769. [CrossRef]

7. Haverson, D.; Bacon, J.; Smith, H.C.; Venugopal, V.; Xiao, Q. Modelling the hydrodynamic and morphological impacts of a tidal stream development in Ramsey Sound. Renew. Energy 2018, 126, 876-887. [CrossRef]

8. Robins, P.E.; Neill, S.P.; Lewis, M.J. Impact of tidal-stream arrays in relation to the natural variability of sedimentary processes. Renew. Energy 2014, 72, 311-321. [CrossRef]

9. Neill, S.P.; Hashemi, M.R.; Lewis, M.J. Tidal energy leasing and tidal phasing. Renew. Energy 2016, 85, 580-587. [CrossRef]

10. Ahmadian, R.; Falconer, R.A. Assessment of array shape of tidal stream turbines on hydro-environmental impacts and power output. Renew. Energy 2012, 44, 318-327. [CrossRef]

11. Neill, S.P.; Jordan, J.R.; Couch, S.J. Impact of tidal energy converter (TEC) arrays on the dynamics of headland sand banks. Renew. Energy 2012, 37, 387-397. [CrossRef] 
12. Gallego, A.; Side, J.; Baston, S.; Waldman, S.; Bell, M.; James, M.; Davies, I.; O'Hara Murray, R.; Heath, M.; Sabatino, A.; et al. Large scale three-dimensional modelling for wave and tidal energy resource and environmental impact: Methodologies for quantifying acceptable thresholds for sustainable exploitation. Ocean Coast. Manag. 2017, 147, 67-77. [CrossRef]

13. Goward Brown, A.J.; Neill, S.P.; Lewis, M.J. Tidal energy extraction in three-dimensional ocean models. Renew. Energy 2017, 114, 244-257. [CrossRef]

14. Manasseh, R.; McInnes, K.L.; Hemer, M.A. Pioneering developments of marine renewable energy in Australia. Int. J. Ocean Clim. Syst. 2017, 8, 50-67. [CrossRef]

15. AUSTeN. Australian Tidal Energy. 2017. Available online: http://austen.org.au/ (accessed on 30 November 2019).

16. Penesis, I.; Hemer, M.; Cossu, R.; Hayward, J.; Nader, J.R.; Rosebrock, U.; Grinham, A.; Sayeef, S.; Osman, P.; Marsh, P.; et al. Tidal energy in Australia-Assessing resource and feasibility to Australia's future energy mix. In Proceedings of the 4th Asian Wave and Tidal Energy Conference, Taipei, Taiwan, 9-13 September 2018; p. 507.

17. Behrens, S.; Griffin, D.; Hayward, J.; Hemer, M.; Knight, C.; McGarry, S.; Osman, P.; Wright, J. Ocean Renewable Energy: 2015-2050: An analysis of ocean energy in Australia. North Ryde CSIRO 2012. [CrossRef]

18. Marsh, P.; Penesis, I.; Nader, J.R.; Couzi, C.; Cossu, R. Assessment of tidal current resources in Banks. In Proceedings of the 13th European Wave and Tidal Energy Conference, Napoli, Italy, 1-6 September 2019; pp. 1-10.

19. Wijeratne, E.M.; Pattiaratchi, C.B.; Eliot, M.; Haigh, I.D. Tidal characteristics in Bass Strait, south-east Australia. Estuar. Coast. Shelf Sci. 2012, 114, 156-165. [CrossRef]

20. Sandery, P.A.; Kämpf, J. Winter-Spring flushing of Bass Strait, South-Eastern Australia: A numerical modelling study. Estuar. Coast. Shelf Sci. 2005, 63, 23-31. [CrossRef]

21. Sandery, P.A.; Kämpf, J. Transport timescales for identifying seasonal variation in Bass Strait, south-eastern Australia. Estuar. Coast. Shelf Sci. 2007, 74, 684-696. [CrossRef]

22. McIntosh, P.C.; Bennett, A.F. Open Ocean Modeling as an Inverse Problem: M 2 Tides in Bass Strait. J. Phys. Oceanogr. 1984, 14, 601-614. [CrossRef]

23. McInnes, K.L.; O'Grady, J.G.; Hemer, M.; Macadam, I.; Abbs, D.J.; White, C.J.; Corney, S.P.; Grose, M.R.; Holz, G.K.; Gaynor, S.M.; et al. Climate Futures for Tasmania: Extreme Tide and Sea-Level Events Technical Report; Technical Report January; Antarctic Climate and Ecosystems Cooperative Research Centre: Hobart, Tasmania, 2011.

24. Fandry, C.B. Development of a Numerical Model of Tidal and Wind-driven Circulation in Bass Strait. Mar. Freshw. Res. 1981, 32, 9-29. [CrossRef]

25. Fandry, C.B.; Hubbert, G.D.; McIntosh, P.C. Comparison of predictions of a numerical model and observations of tides in bass strait. Mar. Freshw. Res. 1985, 36, 737-752. [CrossRef]

26. Wijffels, S.E.; Beggs, H.; Griffin, C.; Middleton, J.F.; Cahill, M.; King, E.; Jones, E.; Feng, M.; Benthuysen, J.A.; Steinberg, C.R.; et al. A fine spatial-scale sea surface temperature atlas of the Australian regional seas (SSTAARS): Seasonal variability and trends around Australasia and New Zealand revisited. J. Mar. Syst. 2018, 187, 156-196. [CrossRef]

27. Fortunato, A.B.; Bertin, X.; Oliveira, A. Space and time variability of uncertainty in morphodynamic simulations. Coast. Eng. 2009, 56, 886-894. [CrossRef]

28. Pinto, L.; Fortunato, A.B.; Freire, P. Sensitivity analysis of non-cohesive sediment transport formulae. Cont. Shelf Res. 2006, 26, 1826-1839. [CrossRef]

29. Nash, S.; Phoenix, A. A review of the current understanding of the hydro-environmental impacts of energy removal by tidal turbines. Renew. Sustain. Energy Rev. 2017, 80, 648-662. [CrossRef]

30. Galibert, G. IMOS Toolbox Version 2.x.x. 2020. Available online: https://github.com/aodn/imos-toolbox (accessed on 21 March 2019).

31. Scherelis, C.; Penesis, I.; Marsh, P.; Cossu, R.; Hemer, M.; Wright, J. Relating fish distributions to physical characteristics of a tidal energy candidate site in the Banks Strait Australia. In Proceedings of the 13th European Wave and Tidal Energy Conference, Napoli, Italy, 1-6 September 2019; pp. 1-8.

32. Perez, L.; Cossu, R.; Couzi, C.; Penesis, I. Wave-Turbulence Decomposition Methods Applied to Tidal Energy Site Assessment. Energies 2020, 13, 1245. [CrossRef] 
33. Coles, D.S.; Blunden, L.S.; Bahaj, A.S. Assessment of the energy extraction potential at tidal sites around the Channel Islands. Energy 2017, 124, 171-186. [CrossRef]

34. DHI. MIKE 21 \& MIKE 3 Flow Model FM, Hydrodynamic Module Scientific Documentation; DHI: Hesholm, Denmark, 2017.

35. Whiteway, T. Australian Bathymetry and Topography Grid. Geosci. Aust. Canberra 2009. [CrossRef]

36. Australian Hydrographic Office Charts. Available online: http://www.hydro.gov.au/prodserv/paper/ auspapercharts.htm (accessed on 1 March 2018).

37. Yongcun, C.; Ole Baltazar, A. Improvement in global ocean tide model in shallow water regions, 2010. In Proceedings of the OSTST, Lisbon, Portugal, 18-22 October 2010.

38. International Electrotechnical Commission. IEC / TS 62600-201 : Marine Energy-Wave, Tidal and Other Water Current Converters and Characterization; International Electrotechnical Committee: Genova, Switzerland, 2015.

39. Copernicus Climate Change Service (C3S). ERA5: Fifth generation of ECMWF Atmospheric Reanalyses of the Global Climate. Copernicus Climate Change Service Climate Data Store (CDS). 2017. Available online: https:/ / cds.climate.copernicus.eu/cdsapp\#!/home (accessed on 5 January 2019).

40. Swan Island: Tasmania Daily Weather Observations. Available online: http://www.bom.gov.au/climate/ dwo/IDCJDW7051.latest.shtml (accessed on 5 January 2019).

41. Soulsby, R. Dynamics of Marine Sands; Thomas Telford Publishing: London, UK, 1997. Available online: https:/ / www.icevirtuallibrary.com/doi/pdf/10.1680/doms.25844 (accessed on 5 January 2018). [CrossRef]

42. Waldman, S.; Bastón, S.; Nemalidinne, R.; Chatzirodou, A.; Venugopal, V.; Side, J. Implementation of tidal turbines in MIKE 3 and Delft3D models of Pentland Firth \& Orkney Waters. Ocean Coast. Manag. 2017, 147, 21-36. [CrossRef]

43. EMEC Orkney. Environmental Impact Assessment (EIA). Guidance for Developers at the European Marine Energy Centre; Technical Report; EMEC Orkney: Stromness, UK, 2008.

44. Thiébot, J.; Guillou, N.; Guillou, S.; Good, A.; Lewis, M. Wake field study of tidal turbines under realistic flow conditions. Renew. Energy 2020, 151, 1196-1208. [CrossRef]

45. Lewis, M.; Neill, S.; Robins, P.; Hashemi, M.; Ward, S. Characteristics of the velocity profile at tidal-stream energy sites. Renew. Energy 2017, 114, 258-272. [CrossRef]

46. Gunn, K.; Stock-Williams, C. On validating numerical hydrodynamic models of complex tidal flow. Int. J. Mar. Energy 2013, 3-4, e82-e97. [CrossRef]

47. Sellar, B.; Wakelam, G. Characterisation of Tidal Flows at the European Marine Energy Centre in the Absence of Ocean Waves. Energies 2018, 11, 176. [CrossRef]

48. Codiga, D. UTide Unified Tidal Analysis and Prediction Functions. MATLAB Central File Exchange. 2020. Available online: https:/ /www.mathworks.com/matlabcentral/fileexchange/46523-utide-unified-tidalanalysis-and-prediction-functionsl (accessed on 22 January 2020).

49. Australian Baseline Sea Level Monitoring Project Hourly Sea Level and Meteorological Data. Available online: http:/ / www.bom.gov.au/oceanography/projects/abslmp/data/index.shtml (accessed on 1 March 2018).

50. Hagerman, G.; Polagye, B.; Bedard, R.; Previsic, M. Methodology for Estimating Tidal Current Energy Resources and Power Production by Tidal In-Stream Energy Conversion (TISEC) Devices; EPRI North American Tidal In Stream Power Feasibility Demonstration Project; 2006. Available online: https://tethys. pnnl.gov/sites/default/files/publications/Tidal_Current_Energy_Resources_with_TISEC.pdf (accessed on 22 January 2020).

51. Gooch, S.; Thomson, J.; Polagye, B.; Meggitt, D. Site characterization for tidal power. In Proceedings of the OCEANS 2009, Venice, Italy, 21-25 September 2009; pp. 1-10.

52. O'Rourke, F.; Boyle, F.; Reynolds, A. Ireland's tidal energy resource; An assessment of a site in the Bulls Mouth and the Shannon Estuary using measured data. Energy Convers. Manag. 2014, 87, 726-734. [CrossRef]

53. Gunn, K.; Stock-Williams, C. Fall of Warness 3D Model Validation Report: ETI REDAPT MA1001 PM14 MD5.2; Technical Report; E.ON New Build Technology: Coventry, UK, 2012. 
54. Dyer, K.R.; Huntley, D.A. The origin, classification and modelling of sand banks and ridges. Cont. Shelf Res. 1999, 19, 1285-1330. [CrossRef]

55. Gibbs, C.; Tomczak, M.; Longmore, A. The Nutrient Regime of Bass Strait. Mar. Freshw. Res. 1986, 37, 451-466. [CrossRef] 